THE DETERMINANTS OF CHILD CARE WORKERS' WAGES AND COMPENSATION:

SECTORAL DIFFERENCE, HUMAN

CAPITAL, RACE, INSIDERS

AND OUTSIDERS

H. Naci Mocan

Deborah Viola

Working Paper 6328 


\title{
THE DETERMINANTS OF CHILD CARE WORKERS' WAGES AND COMPENSATION: \\ SECTORAL DIFFERENCE, HUMAN \\ CAPITAL, RACE, INSIDERS \\ AND OUTSIDERS
}

\author{
H. Naci Mocan \\ Deborah Viola
}

\author{
Working Paper 6328 \\ http://www.nber.org/papers/w6328

\section{NATIONAL BUREAU OF ECONOMIC RESEARCH 1050 Massachusetts Avenue \\ Cambridge, MA 02138}

December 1997

We thank David Blau, Linda Edwards, Michael Grossman, Cordelia Reimers, Ann Dryden Witte and Jeffey Zax for helpful comments. Timothy Potter and Jennifer Giellis provided outstanding research assistance. Any opinions expressed here are those of the authors, and should not be assumed to be those of the University of Colorado at Denver, New York Medical College or the National Bureau of Economic Research. Naci Mocan thanks Martin Feldstein and the NBER for support through a Nonprofit Sector Research Grant.

(C) 1997 by H. Naci Mocan and Deborah Viola. All rights reserved. Short sections of text, not to exceed two paragraphs, may be quoted without explicit permission provided that full credit, including (C) notice, is given to the source. 
The Determinants of Child Care Workers' Wages

and Compensation: Sectoral Difference, Human

Capital, Race, Insiders and Outsiders

H. Naci Mocan and Deborah Viola

NBER Working Paper No. 6328

December 1997

JEL Nos. J13, J31, J41, J44, J51, L3, J24

\section{ABSTRACT}

This paper investigates the determinants of wages and compensation in child care centers for teachers and aides. Nonprofit status has no across-the-board impact on wages. The extent of the wage premium enjoyed by some nonprofit workers depends on the category of the nonprofit center, occupation of the workers, and their race. The rate of return to an additional year of tenure is 2 percent for both teachers and aides. The return to prior experience is one percent for teachers and zero for aides. An additional year of general education brings about a 5 percent increase in teacher wages, and half of that amount in aide wages. Specialized training influences teacher wages, but has less impact on aide wages. Unionization has a large impact on both wages and compensation of teachers and aides. Alternative wages of the workers are positively related to teacher and aide wages. An increase in local unemployment decreases aides' wages, but has a positive impact on the wages of teachers. There is evidence of profit sharing in the case of aides, but not teachers. An increase in center size positively impacts teacher wages.

This body of evidence indicates both teacher and aide remuneration have non-competitive flavors, where the case is more compelling for aides.

H. Naci Mocan

Department of Economics

University of Colorado at Denver

Campus Box 181, PO Box 173364

Denver, CO 80217-3364

and NBER

NMOCAN@CARBON.CUDENVER.EDU
Deborah Viola

New York Medical College

Graduate School of Health Sciences

The Learning Center, Room 310

Valhalla, NY 10595 


\section{THE DETERMINANTS OF CHILD CARE WORKERS' WAGES AND COMPENSATION: SECTORAL DIFFERENCE, HUMAN CAPITAL, RACE, INSIDERS AND OUTSIDERS}

\section{$\underline{\text { I. Introduction }}$}

Employment growth in the child care industry has been much more rapid than the growth of most industries. Since 1972, the number of child care jobs has grown by almost 250 percent, reaching more than 500,000 jobs in 1994 (Goodman 1995). The demand for child care and the employment in this industry is expected to grow even more rapidly in the near future because of recent welfare reforms.

Wages of child care workers are low. Blau (1992) reports that average wages of teachers in the child care industry between 1976 and 1986 was $\$ 3.63$ in 1979 dollars, which was 1/3 less than the wages of other workers. Furthermore, child care workers' real wages were nearly constant between 1976 and 1986 (Blau 1992). In this paper we report that the average wages of child care teachers was $\$ 7.53$ in 1993. Given that the 1976-86 wage of $\$ 3.63$ in 1979 dollars corresponds to $\$ 7.22$ in 1993 using the consumer price index, this indicates that child care workers' wages increased only 4 percent in real terms from early-1980s to early-1990s. Blau (1993) estimated the elasticity of labor supply to child care, and found an elasticity in the range of 1.2 to 1.9. This may explain child care workers' stagnant real wages despite the rapid growth in demand, and predicts that no substantial wage increases are to be expected even if the demand for child care increases significantly due to the transition from welfare to work initiatives in welfare reform.

It has been noted that the average quality of center-based child care provided in the United States is below the level that is considered developmentally appropriate (Mocan 1997, Whitebook et al., 1990). The low- 
quality, low-wage aspect of the industry prompted some child care advocates to promote exogenous increases in child care workers' wages, possibly through government grants to centers, as a means to raise the quality of the services (Vardel and Whitebook, 1995).

Despite its importance as a rapidly growing industry and the obvious public policy issues involved, there have been only two published studies which investigated the determinants of wages in the child care industry (Preston 1988 and Blau 1992). This paper investigates the determinants of wages and compensation (wage plus nonwage benefits) in child care centers. It utilizes a recent data set, which includes extraordinary detail on 398 day care centers from California, Colorado, Connecticut and North Carolina. The data contain more than 50 worker and firm attributes, some of which have not been employed by previous researchers (see Table 1). Thus, we are able to separate out the impacts of various covariates of child care workers' wages and compensation better than previous studies, and obtain new insights into their determinants.

As will be explained in Section II in detail, the center-based segment of the child care industry consists of nonprofit and for-profit sectors. There is a long-standing controversy regarding the relative efficiency of these sectors in producing child care services. Our data set enables us to investigate the differences in wages and compensation not only between the two sectors, but also within the sectors. We find that sector affiliation (nonprofit vs. for-profit) does not impact wages or compensation, but there is significant within-sector variation due to institutional and ownership structures. We also discover a race effect on wages and compensation. Furthermore, we document that this effect works in favor of, or against minorities as a function of the institutional characteristics of the centers.

The existence of inter-industry wage differentials is well documented. Workers with similar productive characteristics, working under similar conditions earn different wages in different industries (for a summary see Dickens and Katz 
1987, Groshen 1991a, and Krueger and Summers 1987). Wage differentials also exist within industries. Establishment and plant level wage variation is significant and persistent over time (e.g. Groshen 1991b, Nolan and Brown 1983). Since in a truly competitive labor market there need be no relationship between wages and establishment characteristics such as financial strength, market power and firm size, this body of empirical evidence gives support to non-competitive theories of wage determination.' Following this literature, we also investigate the validity of a non-competitive wage determination framework.

Previous research found that the industry wage structure is similar for workers in different occupations; i.e. all workers in some industries are paid more than similar workers in other industries (Dickens and Katz 1986). We estimate wage and compensation equations separately for teachers and assistant teachers (aides) in day care centers. Our results show that although there are similarities in the determinants of wages and compensation for teachers and aides, there exist important differences.

Another feature of the child care industry is that it fits into the profile of a secondary labor market. Almost all workers in this industry are female, the wages are low (Blau 1992, Mocan 1997), turnover is high and returns to education are low (Blau 1992). We find that there exists a "secondary market" within the child care industry. More precisely, we show that the returns to education and experience are substantially different between teachers and assistant teachers. Drawing on two recent papers (Krueger 1997, Blau 1997b), we provide an explanation for this phenomenon.

Finally, we control for unmeasured productivity by exploiting the richness of the data set. Section II details the issues discussed here and provides a

1 Perhaps the most prominent of these are the insider-outsidermodels (Lindbeck and Snower 1988, Carruth and Oswald 1987), and the efficiency wages theory. For a summary of various versions of the efficiency wages theory see Katz (1988). 
summary of the results. Section III describes the data set and the empirical methodology. Section IV reports the results and Section V is the conclusion.

II. Background and the Summary of the Results

\section{A. Nonprofit vs. For-profit Sector}

Center-based child care is a mixed industry where nonprofit and forprofit centers co-exist. As summarized by Preston (1988), the theory of property rights predicts that nonprofit institutions may generate rents for their workers. This is partly because there is no owner to which the nonprofit manager is held accountable, which lessens the incentive for managers of nonprofit organizations to operate efficiently. As a result, there is reason to expect that nonprofit enterprises pay higher wages to comparable workers than their for-profit counterparts. Preston (1988) using data from child care centers collected in 1976-1977 found a 5 to 10 percent positive nonprofit salary differential in the government subsidized segment of the industry. In the competitive segment of the industry there was no evidence of a salary differential. ${ }^{2}$ Similarly, Borjas, Frech III, and Ginsburg (1983), using data on Nursing Homes found subtle variations in the incentive structures that create wage differences among firms within a particular ownership category (for-profit firms), and that for-profit firms paid the lowest wages, supporting the property rights argument.

Following the previous literature, we first classify the centers into two groups as nonprofit and for-profit. In agreement with earlier studies, estimation of wage equations under this structure yields the result of a nonprofit wage premium. However, when we control for fine breakdowns within each sector, industry using Preston (1988) differentiates between competitive and noncompetitive segments of the industry using the Federal Interagency Day Care Requirements (FIDCR). She indicates that centers that were federally funded and subjected to FIDCR regulations had a certain amount of monopoly power allowing profits to persist. On the other hand, firms subject to only state and local regulations were operating in a more competitive environment. FIDCR was abandoned in 1980, and federally funded centers were required to follow state and local regulations exclusively (Preston
1988 , p. 341). 
such as whether the center is part of a national chain, or publicly owned and operated, publicly supported, regulated, or a religiously affiliated center, we obtain different results. We find that sector affiliation (non-profit vs. for-profit) has no impact on wages and compensation, but there is substantial variation in wages within the nonprofit sector depending upon ownership. Furthermore, these wage premiums depend upon the racial composition of staff. For example, we find that publicly owned and operated centers pay higher wages to their staff so long as the staff consists of minorities.

\section{B. Non-competitive wage determination}

The influence of the insider (from within the firm or establishment) and outsider (from outside the firm) pressures on wage determination have been investigated fairly extensively. Currie and McConnell (1992) reported the impact of firm-specific variables such as sales, financial liquidity and the capital-labor ratio on negotiated wages. Blanchflower, Oswald and Garrett (1990), and Nickell, Vainiomaki and Wadhwani (1994) documented that the establishment's financial strength and market power, as well as the presence of unions and the local unemployment rate were related to the wage rates paid by the firms. Main and Reilly (1993), Brown and Medoff (1989), Evans and Leighton (1989) discovered a positive relationship between the size of the firm and wages. Dickens and Katz (1987), Blanchflower, Oswald and Sanfey (1996), Christofides and Oswald (1992), Abowd and Lemieux (1993) documented the link between profitability per worker and wages.

We find that particular insider, outsider and institutional forces that influence wages and compensation of teachers are different from those that influence the wages and compensation of aides. We detect that the profitability of the child care center, alternative wages of the workers (approximated by the service sector wage in the local area) as well as the local unemployment rate influence wages and compensation. These impacts are not always symmetric 
between occupations (teachers and aides) and between wages and compensation. For example, we find strong evidence for the "wage curve" hypothesis (Blanchlower and Oswald 1993) for aides, but not for teachers. Similarly, there is evidence for profit-sharing in the case of aides, but not teachers. Unions positively impact wages and compensation of both teachers and aides, where the impact on compensation is particularly strong for aides. Perhaps the most interesting and compelling support for non-competitive wage determination is the firm size effect. We document a strong and robust relationship between firm size and both wages and compensation for teachers, but not for aides. We contend that this evidence supports the monitoring-based efficiency wages theory. This body of evidence could be taken as an indication for non-competitive wage-setting practices, especially for aides; although we offer competitive explanations as well.

\section{Secondary Labor Market and Returns to Human Capital}

The child care labor market has the attributes of a secondary labor market with low wages, low returns to human capital and high turnover. In our data set the average wage of teachers in day care centers was \$7.53 in 1993. Similarly, Mocan (1997) reports that in 1993, average center wages for child care workers with 12 or fewer years of education was $\$ 5.75$, and average wages of workers with 16 or more years of education was $\$ 7.53$. The rate of turnover among child care workers is reported to be as high as 40 percent (Phillips and Whitebook, 1986). In our data set, the turnover rate is around 40 percent; and even the 21 percent turnover rate reported by Blau (1992) is much higher than that of other workers.

Although low wages and high turnover are characteristics of a secondary labor market, a formal test is the investigation of the rate of return to education and job tenure in the secondary market in comparison to the returns in a primary labor market (e.g. Neuman and Ziderman 1986, Mayhew and Rosewell 1979). 
Blau (1992) reports that experience, approximated by the age of the child care worker, has no impact on wages. The same is true for education in case of private household child care workers and teachers. He reports a 5 percent rate of return for nonhousehold child care workers. These low or non-existent returns to human capital support the proposition that the child care industry fits the description of a secondary labor market.

In this paper we find positive but low rates of return to education, job tenure and experience for teachers. Interestingly, however, we find that for aides, the return to experience is zero; and the return to education is only half that of teachers. At first glance, this picture seems like a segmented labor market within a secondary labor market, but based on recent research we maintain that this outcome reflects a rational decision on the part of the firms. Blau (1997b) and Krueger (1997) show that the productivity of aides is much lower than the productivity of teachers. Given this, it is not surprising that centers do not award additional education and experience of aides as heavily as they do for teachers.

\section{Unobservable Productivity}

One possible explanation of inter- (and intra-) industry wage differentials is the sorting of workers by quality across industries (or firms). For example, if different firms use different technologies in a particular industry, and if certain technologies are more sensitive to worker quality (conditional upon observable worker attributes), this may generate sorting of workers by ability. And given that productivity is correlated with ability, this would create intra-industry wage differentials. Similarly, job matching in the presence of imperfect information on worker quality could lead to sorting by ability (Jovanovic 1979a, 1979b). ${ }^{3}$ We investigate the impact of ability on wages by exploiting information about the

3 See Groshen (1991b) for a review of ability sorting. 
quality of the services provided by the centers. Our results show that unobserved productivity has a small positive influence on wages and compensation.

\section{Data and Statistical Analysis}

This study employs a recent data set obtained from child care centers in California, Colorado, Connecticut and North Carolina. ${ }^{4}$ The data are based upon a stratified random sample of approximately 100 day care centers from each participating state, with equal representation of for-profit and nonprofit programs, providing full-time year-round care. The data were obtained by actual visits to the centers during the spring of 1993. Data collectors gathered in-depth financial information on center costs, amounts and sources of revenue, and amounts and sources of donations through on-site interviews and reviews of center records with center administrators or owners. Also, two observers visited each center for one day to gather data on the quality of the services produced (explained below in detail). As a result, the extraordinary detail of the data allows for control of the job environment, and worker and firm characteristics with more precision than was possible before.

The theory of equalizing differentials and matching provides guidance for the empirical model. Following closely the model described by Rosen (1986), assume that a child care teacher's utility function depends on consumption $C$, and a vector of center characteristics $S: U=U(c, s)$. A teacher is endowed with characteristics $t$, and searches out a center with characteristics $s$. This is determined by maximization of $U$ under the condition that $c=w+y$ where $w$ is the wage rate and $y$ is nonwage income. Similarly, a center endowed with $s$, searches for teachers with desired characteristics, $t$. Centers have quality

4

The data were compiled with the collaboration of economists, psychologists and child development experts from University of Colorado at Denver, Yale University, University of North Carolina at Chapel Hill and UCLA. 
production functions, $q=q(t, s)$ where $q$ is the quality of the services. All types of centers, for-profit or nonprofit aim to minimize costs, given $q$ and $s$. It follows that the equilibrium wage is a function of $s$ and $t: w=w(s, t)$.

Consequently, empirical implementations that stemmed from this framework relied on estimating wage equations as a function of teacher and school characteristics (e.g. Toder 1972, Antos and Rosen 1975, Kenny and Denslow 1980)

Following this literature, and the literature that estimates firm-level earnings equations (e.g. Preston 1988, Blanchflower, Oswald and Garrett 1990, Cappelli and Chauvin QJE 1991, Currie and McConnell 1992, Christofides and Oswald 1992, Bhargava 1994, Hildreth and Oswald 1997; Doms, Dunne and Troske 1997), the log of average center wages for teachers and aides is regressed on human capital and demographic variables, center attributes, variables representing insider and outsider forces and region dummies. More specifically, we estimate

$$
\ln \left(Y_{\mathrm{ij}}\right)=\alpha_{\mathrm{j}}+\Sigma \beta_{\mathrm{kj}} \mathrm{X}_{\mathrm{ki}}+\Sigma \gamma_{\mathrm{mj}} \mathrm{P}_{\mathrm{mi}}+\Sigma \delta_{\mathrm{nj}} \mathrm{H}_{\mathrm{nji}}+\Sigma \lambda_{\mathrm{qi}} \mathrm{D}_{\mathrm{qi}}+\xi \nu_{\mathrm{i}}+\epsilon_{\mathrm{ij}},
$$

where $Y_{i j}$ is the average wage paid at center $i$ to the $j$ th type of worker, weighted by hours worked for each worker in the $j$ th category $(j=I$ for teachers, $j=2$ for aides). $\mathrm{X}_{\mathrm{k}}$ stands for various center attributes (see Panel B of Table 1). $P$ represents other center characteristics not included in $X$. These are the program variables that capture the scope of the services provided by the center (such as the availability of weekend care, Head Start programs, etc.), which are displayed in Panel $\mathrm{C}$ of Table 1. Human capital characteristics of workers in the $j$ th category are represented by $H$ in Equation (1). In addition to age, previous experience, tenure, and general education, we also have 11 measures for specific child care training of the teachers and aides. D stands for state dummies included 
to capture state fixed-effects, and $\nu$ is a measure of unobserved productivity as explained below.

The Quality of the Services Provided and Unobservable Worker Productivity

The data set contains a measure of the quality of the services produced by the child care centers. In this section we briefly describe the data that are collected to create the quality index, the theory of the quality production function, and how it relates to our analysis.

The index of process quality is widely used in early childhood literature to gauge the quality of the services produced at child care centers, and has been shown to be positively related to children's social and cognitive developments (Lazar and Dalington 1982, Ramey and Campbell 1991). Center process quality is influenced by classroom structures such as teacher education, experience, and the number of children per teacher, as well as center structural characteristics such as the number of children served, and the age groups. The center's process quality is also affected by the child care environment, specific aspects of teacherchild interactions, and the style of teaching. Thus, center process quality is produced by a "quality production function", where observable -structural- center characteristics are the inputs, and process quality is the output.

In each of the 398 centers in the data set, two classrooms were randomly selected: one from the older children (30 months and older) and one from the younger groups. In each room well-established global measures of the child care process were employed by trained observers to assess the quality of the 
operation. ${ }^{5}$ To create a single score to represent classroom process quality, an index was created using principal components techniques. The center level process quality (QUALITY) is the average classroom quality, weighted by enrollments at the appropriate age levels. It has a seven point scale, with a range from inadequate (1) to minimal (3), good (5) and excellent (7). This is the same index recently employed by Mocan (1995), Mocan et al. (1995) and Mocan (1997). Its descriptive statistics are reported in Panel B of Table 1 (QUALITY). Mocan et al. (1995) estimated a quality production function where the process quality index is explained by structural center characteristics and human capital variables of teachers and aides. Blau (1997a) estimated similar quality production functions, where center quality is measured by some individual components of the process quality employed by Mocan et al. (1995) and Mocan (1995, 1997). Both Blau (1997a) and Mocan et al. (1995) find that center-level quality production functions explain at most 50 percent of the variation in center quality. This implies that at least 50 percent of the variation in the quality of the child care services produced by the centers is not explained by observable worker and center characteristics, but by unobservable center attributes. The prime candidate for those unobservables is worker quality and/or managerial ability, not captured by traditional measures such as education, experience and tenure.

In summary, previous research on child care quality estimated production functions of the following form.

$$
\mathrm{q}_{\mathrm{i}}=\mathrm{a}+\Sigma \mathrm{b}_{\mathrm{k}} \mathrm{S}_{\mathrm{ki}}+\Sigma \mathrm{c}_{\mathrm{n}} \mathrm{H}_{\mathrm{ni}}+\Sigma \mathrm{d}_{\mathrm{q}} \mathrm{D}_{\mathrm{qi}}+\nu_{\mathrm{i}}
$$

\footnotetext{
s See Mocan (1995) for details.
} 
where $q$ represents the quality of the services produced by the center, $S_{k}$ stands for the same center attributes employed in Equation (1) above, plus additional structural process quality measures such as the staff-child ratio, and the group size. Human capital characteristics of teachers and aides are represented by $H$ in Equation (2). D stands for state dummies included to capture state fixed-effects. The subscript $i$ indexes the $i$ th center.

As described above, quality production functions like (2) explain less than half of the variation in center quality, which suggests that the error term $\nu_{\mathrm{i}}$ contains substantial information on unobserved worker quality that impact the quality of the services produced above and beyond that predicted by the covariates of Equation (2). To capture those unobserved worker characteristics, we estimated Equation (2) by regressing center process quality on the variables displayed in Panels B, C, D and E of Table 1 (excluding the service wage, the unemployment rate and center profits). The residuals of this regression, $\nu_{\mathrm{i}}$ (the component of center quality, not explained by observable worker and firm characteristics) are used as a proxy for unobservable worker quality in wage Equation (1), denoted by PRODUCTTVTTY.

Descriptive statistics are provided in Table 1. Means and standard deviations of the variables are calculated for nonprofit centers, for-profit centers and all centers in the sample. $A\left({ }^{*}\right)$ after the variable name in the first column indicates that the means of the variables are statistically different between nonprofit and for-profit centers at the 10 percent level or less. The last column of Table 1 displays state codes when the mean of the corresponding variable is different between the two sectors (nonprofit and for-profit) in that particular state. For example, the first variable of the Table (TEACHER-WAGE) is the average 
center wage for full-time teachers. The mean teacher wage is $\$ 8.29$ in the nonprofit centers and $\$ 6.78$ in the for-profit centers; and the difference is statistically different from zero. Furthermore, the mean teacher wage is different between the sectors in all four states [California (CA), Colorado (CO), Connecticut (CT), and North Carolina (NC)].

\section{Wages and Compensation}

Panel A of Table 1 presents the descriptive statistics for wages and compensation of teachers and assistant teachers, center profits in the fiscal year 1992. Center average wages and compensation are calculated for full-time workers, where hours worked by a particular worker is at least 30 per week. Using 35 hours per week as the cut-off for full-time did not change the results. $T E A C H E R-W A G E$ stands for the average wage of full-time teachers at the center, weighted by hours worked. $A I D E-W A G E$ is the average wage of full-time assistant teachers at the center, weighted by hours worked. TEACHER-COMP is the average hourly compensation of full-time teachers; $A I D E-C O M P$ is the average hourly compensation of full-time aides. The detailed description of the creation of the compensation variable is described below in the Appendix.

Profits, Alternative Wage, Local Unemployment and Other Center Characteristics

Panel B displays the descriptive statistics of center profits, alternative wages of the workers, the local unemployment rate and other center characteristics. UNEMPRATE is the 1993 unemployment rate in the city where

6 Having previous year's profits enables us to avoid the simultaneity between wage and profits, provided that profits and the error terms of the wage equations are uncorrelated over time. 
the center is located. The zip codes of the centers are used to determine the city in which the center is located. The unemployment rates for the corresponding cities are obtained from the U.S. Bureau of Labor Statistics, Local Area Unemployment Division. For the cities where BLS figures were unavailable, the unemployment rates are imputed as the average unemployment rates of the neighboring cities within a 20 mile radius. The alternative wages of the workers are measured by county level average wages in the service sector (SERVICE $W A G E)$ in 1993. The FIPS codes of each center were matched with the countylevel data obtained from the Regional Economic Information System.

Center profits are defined in two alternative ways. The first one is the accounting profits per hour of labor (PROFIT-AC), which is the difference between revenues and expenses, divided by total labor hours. The data set contains dollar values of the following variables for the Fiscal Year 1992: Total revenue, total wages (payroll), total nonwage benefits (expenses on life, health and disability insurance, workers' compensation, unemployment insurance and FICA or equivalent), education costs of the staff, sub-contracting expenditures, expenditures on food, insurance and occupancy, overhead and other operating expenses. The difference between total revenue and the sum of the expenditure items listed above is the net accounting earnings - or profits of the center.

The second measure of center profits is economic profits. Because nonprofit centers receive more donations when compared to for-profit centers, failure to account for the value of donations would create an inaccurate picture as to the relative costs of nonprofit centers. The data set contains information on line-item donations such as food, equipment, facilities, insurance and supplies. It also contains information about individual volunteers, including the hours donated 
by each volunteer, and the job performed at the center. The value of volunteer services is calculated by multiplying the volunteer hours by the wage rate of the paid labor doing similar work.

Some for-profit centers are owned and operated by individuals who are also the directors of the center. For those owner-directors who did not report a wage or salary, we imputed the salaries by multiplying their hours by the highest wage at the center plus 23 percent, which is the mean premium a director receives above the highest wage of the center.

Thus, economic profits are calculated as the accounting profits described above plus the total value of donations minus the imputed salaries of ownerdirectors. PROFIT-EC is the economic profits of the centers in the fiscal year 1992 divided by the total labor hours. As Panel A of Table 1 shows, nonprofit centers on the average pay higher wages and compensation to both teachers and assistant teachers. Nonprofit institutions are not prohibited from earning profits. They are prohibited from channeling these profits to the individuals who have control over the institution (see Hansmann 1986). The average accounting profits per hour of worker is 42 cents in the nonprofit centers and 86 cents in the forprofit centers. Although the difference is statistically significant, it is due to the difference between sectors in California. In the other three states the difference between average net earnings is not different between for-profit and nonprofit sectors.

Economic profits are different from the accounting profits in a predictable way. Deduction of imputed owner-director salaries reduced the average profits of the for-profit centers, and inclusion of the donations increased the average profits of the nonprofit centers. In the whole sample economic 
profits are not different between nonprofit and for-profit sectors; although in Colorado and Connecticut the mean economic profits of the nonprofit centers is larger than their for-profit counterparts.

Nonprofit centers are located in cities with higher unemployment rates than their for-profit counterparts. In the whole sample the average unemployment rate for the cities where the nonprofit centers are located is 6.64 , whereas it is 6.04 for-profit centers. Only in North Carolina there is no statistically significant difference between the unemployment rates in the localities of nonprofit and forprofit centers.

FOR-PROFIT takes the value of 1 if the center is for-profit, and 0 if it is nonprofit. NATIONAL CHAIN is also a dichotomous variable, indicating whether the center is part of a for-profit national chain. ONSITE is set to 1 if the center is a worksite child care center, and zero otherwise. SPECIAL REGUL is 1 if the center receives public money, either from the state or federal government, tied to higher standards (above and beyond normal licensing regulations), and 0 otherwise. This group includes Head Start programs, centers where 20 percent or more of their enrollment constitute special needs children, special preschool programs sponsored by the State or Federal Department of Education, and other special programs in Connecticut and California.

PUBLIC-AUSPICE is set to 1 for centers that are owned and operated by public agencies. Examples include public colleges, hospitals, and city departments of family services.

PUBLIC-SUPPORT is another dichotomous variable which takes the value of 1 if the center is not publicly owned or operated, but receives more than 50 percent of its revenue from public grants, public fees and USDA reimbursement. 
RELIGIOUS is 1 if the center has a religious affiliation (e.g. church-based centers), and zero otherwise. UNION is 1 , if teachers and/or aides are unionized. There are 18 unionized centers in the sample, all in nonprofit centers. Of these, 14 are publicly owned centers (PUBLIC-AUSPICE), 2 are publicly supported centers (PUBLIC-SUPPORT) and 2 are religious centers.

$R A T I O$ stands for the mid-morning staff-to-child ratio of the center, weighted by the proportion of the relevant age group. GROUP is the midmorning group size of the children weighted by the proportion of the relevant age group. INFANT-RATIO is the percentage of infants at the center; PRESCH$R A T I O$ is the ratio of preschool aged children at the center. These variables are employed in the quality production function depicted in (2).

SUBSIDIZED represents the percent of children that are subsidized by a government or other agency, such as the State or County Department of Social or Human Services, United Way, etc. WHITE CHILDRN is the percentage of white children at the center.FTE-CHILDREN is the total number of full-time equivalent children at the center. TEACHER-WHITE is the percent white teachers; $A D D E$ WHITE is the percent of white assistant teachers at the center. CENTER AGE is the years that the center has been in operation.

Nonprofit centers serve a higher percentage of subsidized children and non-white children. They have a higher percentage of non-white teaching staff, and the proportion of preschool children is larger in nonprofit centers. The proportion of infants is higher at the for-profit centers. For-profit centers are larger (76 full-time equivalent children as opposed to 60 in nonprofit centers), and younger (an average of 10 years in operation vs. 16 years). 


\section{Center Programs}

Panel $\mathrm{C}$ of Table 1 displays the information about the various programs offered by the centers. There are 5 different categories, ranging from whether the center offers a before and after school care program (BEFORE-AFTER) to whether the center is a Head-start program. As can be seen, for-profit centers offer before-and-after school care, part-day, and part-day extended care programs more heavily than nonprofits.

\section{Human Capital Characteristics of the Workers}

Panel D of Table 1 displays descriptive statistics of age $(A G E)$, prior child care experience (EXPERIENCE), tenure at the center (TENURE), and general education (EDUCATION) of the teachers. Alternative general education variables are created by calculating the total number of hours worked by teachers with no high school degree divided by total teacher hours in the center ( $T$ NOHIGHSCH), and the ratio of total hours worked by teachers with a high school degree to total teacher hours $(T-H I G H S C H)$. Similarly, the proportion of teacher hours associated with some college attendance (T-SOMECOLL), the proportion of teacher hours with college degree (T-COLLEGE), and the proportion of teacher hours with graduate degree (T-POSTCOLL) are calculated.

The 11 variables in the second group in Panel D display information on specialized child care education and training of the workers. For example, NOTRAINING is the ratio of the hours of teachers who have no specific child care education or training to total teacher hours. Similarly, TRAINING-2 is the proportion of teacher hours with in-service workshops at the center, and 
TRAINING-11 is the percentage of teacher hours with a graduate degree in early child education, child development, etc.

Panel E displays the descriptive statistics of aides. As panels B, D and E demonstrate, nonwhite teachers and aides constitute a higher fraction of total teachers and aides in nonprofit centers. Nonprofit centers have older teachers, slightly more experienced teachers with slightly more tenure. They have more teachers with post-college degrees, less teachers with only a high school education, and more teachers with specialized training.

As for aides, nonprofit centers have older aides, with slightly more experience and slightly more tenure than their for-profit counterparts. They also have more aides with special training. On the other hand, aides in for-profit centers have more education. For profit centers have less aides with no High School degree and more aides with a college degree.

\section{Empirical Results}

Wage Equations: Auspice and Race

In this section we describe wage regression results obtained from estimating Equation (1), separately for teachers and aides. The model is estimated by GLS. ${ }^{7}$ The results are presented in Table 2 . To make the exposition easier, the Table categorizes the variables by type. Section E of Table 2, titled "Race", includes "WHITE TCH/AIDE", which is the proportion of white teachers or aides at the center, WHITE CHILDRN, which is the proportion of

7 Observations are wighted by the inverse of the square root of the number of observations of staff that are used to create the average wages. 
white children at the center and the interaction between the two (WHTSTAFF*WH $\mathrm{CH}$ ), as well as the interaction between auspice variables (RELIGIOUS, PUBLIC-AUSPICE, SPECIAL REGUL, etc.) and the proportion of white teachers (in column 2), and aides (column 4).

The panel A of Table 2 (Sector Characteristics) demonstrates that there is no nonprofit wage differential for teachers and aides after controlling for firm and worker characteristics. The coefficient of FOR-PROFIT is never significant in either wage or compensation equations (reported below). If we omit all auspice variables depicted in Panel A of Table 2 but FOR-PROFIT, we obtain a negative and statistically significant coefficient FOR-PROFIT. This indicates that classification of the centers into two sectors as for-profit and nonprofit creates a misleading picture regarding the impact of auspice on wages. Different subgroups of the nonprofit sector have differential impacts on wages, as will be discussed below; but the nonprofit vs. for-profit distinction has no influence on wages once the sub-sectoral differences are controlled for.

The results show that publicly owned and operated centers (PUBLICAUSPICE) pay a wage premium to both teachers and aides. However, the full picture is not contained in the coefficients of PUBLIC-AUSPICE. The interaction variables between sub-sectors and racial composition of staff (reported in Panel E of Table 21) contain interesting information. As can be seen in Panel E, the interaction between PUB-AUSPICE and percent white teachers (the coefficient of AUSP*WH TCH/AIDE in column 2 and PUB-AUSPICE and percent white aides (the coefficient of $A U S P^{*} W H T C H / A I D E$ in column 4 are negative and significantly different from zero. Thus, the impact on teacher wages of a publicly-owned and operated center is $0.25-0.23 \times$ T-WHITE, where T-WHITE is 
the percent white teachers at the center. The mean value of percent white teachers in the non-profit sample is 0.64 . Thus, a publicly owned center in which 64 percent of the teachers are white, pays 10 percent higher wages than non-publicly owned centers. Note that the interaction term is negative, indicating that as the percentage of white teachers goes up, the wage premium associated with being a publicly-owned center goes down. For example, if the publicly owned center's teachers are all white, then the wage premium is only two percent, whereas if all teachers are non-white, then teachers have 28 percent higher wages in comparison to non-publicly owned centers. ${ }^{8}$ Column 4 shows that the percentage wage premium for aides in the same type of centers is 0.41 $0.48 \times \mathrm{A}-$ WHITE, where A-WHITE is the proportion of white aides at the center. If the proportion of white aides is 0.52 (the average in the nonprofit centers), then publicly owned centers pay 16 percent higher wages to their aides. If all aides are non-white, the premium is 50 percent, and if all aides are white, the premium is negative seven percent. This result indicates that publicly owned and operated centers pay a premium to minority teachers and aides. This may be an extension of affirmative action policies, or alternatively, it may be a protection against discriminatory accusations. A similar relationship appears in publicly supported centers for teachers. Panels A and E of Table 2 show that if all teachers in publicly supported centers (PUBLIC-SUPPORT) are minority, the wage premium is zero, but as the proportion of white teachers goes up the wage premium becomes negative.

\footnotetext{
The percentage impact of a dummy variable on the dependent variable is $\exp \{\beta-1 / 2 \operatorname{var}(\beta)\}-1$, where $\beta$ is the estimated coefficient of the dummy variable, and $\operatorname{Var}(\beta)$ is its variance (Kennedy 1981).
} 
The race impact also appears in religiously owned centers for aides, but in the opposite direction. The coefficient of RELIGIOUS in aides wage regressions (column 4) is negative, but the interaction between RELIGIOUS and percent white aides in Panel $\mathrm{E}$ is positive and significant. This means, for example, that aides who work at religiously owned centers where the proportion of white aides is 50 percent, receive wages that are six percent lower than those who work at non-religious centers. If all aides in the religious center are minority, then their wages are around 15 percent lower than aides in nonreligious centers. If, however, all aides are white in a religious center, then their wages are 2 percent higher in comparison to aides at a non-religious center. For teachers at religiously affiliated centers there is no race impact. Their wages are 11 percent lower than teachers who work at non-religious centers.

Similarly, average wages of aides in centers under special regulations (SPECIAL REGUL) differ from other centers as a function of the race composition. If all aides of the publicly regulated center are minority, their wages are not different from unregulated centers. If 50 percent of aides are white (sample average) then aide wages are eight percent higher; and if all aides are white, their wage ares are 17 percent higher. ${ }^{9}$

These results are interesting, because they document, for the first time, that although there is no wage premium associated with the nonprofit sector, there exists a very significant variation in wages for both teachers and assistant teachers

9 The interaction variables of the proportion of white teachers/aides with FOR-PROFIT, ONSITE and NATIONAL CHAIN were never significant. Defining the race composition of staff as percent black and Hispanic, as opposed to percent white, did not change the results. 
within the nonprofit sector, and they depend on the racial composition of the staff.

Some earlier work reported a positive relationship between the proportion of minority students and teacher wages in public schools (Toder 1972, Antos and Rosen 1975), and argued that this was evidence for compensating differentials. In our case, we control for the race of children (WHITE CHILDRN), the race of the teachers or aides (WHITE TCH/AIDE), as well as the interaction between the two (WHTSTAFF*WH CH). Therefore, the wage premiums that are found in our paper are not reflections of compensating differentials due to race composition. Furthermore, the results are obtained in the presence of detailed human capital controls and the control for unobserved productivity. Thus, these wage premiums appear to be reflections of racial preferences of the employers.

\section{Human Capital}

The relationship between wages and human capital characteristics of teachers and aides, which are displayed in Panel B of Table 2, could be considered equilibrium loci that emerge following worker and firm matching. Thus, the coefficients of human capital variables can be considered as approximations to return to human capital. An additional year of prior child care experience increases teacher wages by 1 percent, but it has no impact on aide wages. For both teachers and aides, if the average tenure at the center increases by one year, this increases wages by approximately 2 percent. The rate of return to general education (EDUCATION) is 5 percent for teachers, but 2.6 percent for aides. 
The 5 percent return to education for teachers, which is consistent with a similar finding reported by Blau (1992), is smaller than the return to education for the labor force in general. Low return to education, coupled with high turnover rates signal the presence of a secondary labor market. However, it is interesting to note that if the labor market in center-based child care is a secondary market, with low return to education and higher turnover rates, the market for aides constitutes a secondary market within this secondary market. The dynamics that generate a secondary labor market are still debated. On the other hand, recent studies provide some insights into the possible reasons for this lack of return to education for aides, which suggest rational behavior on the part of the employers. Using NLSY, Blau (1997) estimated production functions for child outcomes as measured by various test scores and the Behavior Problems Index. He found that small group sizes during the second three years of life has small but positive effects on child outcomes, but there was no relationship between staff-child ratios and child outcomes. The same finding appeared in other studies (The National Day Care Study; Ruopp et al. 1979, Krueger 1997). The finding that group size matters, but staff-child ratio does not implies that aides do not significantly contribute to child outcomes or the quality of the services produced. In other words, it is a better strategy for the center, to have a small group size and one teacher rather than a large group size coupled with a teacher and an aide. Given the implied lack of marginal productivity of aides presented by the studies cited above, it is not surprising that aide education is not rewarded by centers.

The variables titled NOTRAINING, TRAINING-2,.., TRAINING-Il represent the extent of specialized training for teachers or aides. A higher 
proportion of teachers and aides with no special child care training (NOTRAINING) is associated with a reduction of teacher and aide wages. Three special education categories are positively related to teacher wages. They are the percentage of teachers who received special training in workshops in the community or at professional meetings (TRAINING-3), the percentage of teachers with AA degrees in early childhood education or child development (TRAINING7), and the percentage of teachers with graduate courses in child development (TRAINING-10).

Column 4 demonstrates that graduate level child development courses (TRAINING-10) positively impact aide wages. A graduate degree in early childhood education (TRAINING-11), has a negative impact on aides' wages. Table 1 shows that only 1.4 percent of all aides have graduate degrees. The work of a person as an aide with a graduate degree in child development may be practical training or an internship as part of a different career path than those of other aides. If that is the case, it would not be surprising for them to get paid less than other aides with less education.

Insiders, Outsiders and the Wage Curve

Panel $\mathrm{C}$ of Table 2 displays the estimated coefficients of insider and outsider variables. Keeping 50 determinants of wages constant, the presence of a union increases teacher wages by almost 19 percent, and aides' wages by 17 percent. The coefficient of SERVICE WAGE is positive and almost has almost the same magnitude in both teacher and aide regressions. This indicates that a rise in the alternative wages of the workers, as measured by the average service sector wage in the county where the center is located, puts upward pressure on 
the wages of child care workers. Evaluated at the mean value of the service sector wage, the coefficients imply an elasticity of 0.19 .

Another interesting result is the relationship between the unemployment rate in the locality of the center and the wages. As the rate of unemployment in the zip-code area of the center goes up the wages paid to aides fall. The coefficient is -0.013 . When evaluated at the mean value of the unemployment rate of the whole sample (6.333), this generates an elasticity of -0.08 , which is remarkably similar those reported by Blanchlower and Oswald (1994). Wages of teachers, on the other hand, are positively related to the local unemployment rate. As the descriptive statistics of Table 1 demonstrate, teachers have more general and specific education and more tenure than aides. This would suggest that they would be more protected from external labor market forces (Beaudry and DiNardo 1991, Card 1995) in comparison to aides. Therefore, we would expect a weaker relationship (in absolute value) between wages and unemployment in case of teachers. Finding a positive relationship between teacher wages and unemployment, however, suggests that different mechanisms may be in place for teachers and aides. One explanation is that centers provide compensating wage differentials to teachers in the spirit of Harris and Todero (1970) and Hall (1970) models, whereas their relationship with aides are based upon a different framework. Another explanation is the following. If the reduction in aides' wages following an increase in unemployment generates a reduction in their work effort, the positive coefficient of unemployment in the teacher wage regression may be an indication of motivation for teachers to compensate for a less efficient group of aides, especially given the evidence that low educated workers (aides) 
and highly educated workers (teachers) are complements in production in child care centers (Mocan 1997).

To test the profit-sharing hypothesis, the wage equations include PROFIT-EC, which represents economic profits per hour of labor as described above. Because wages pertain to the remuneration in 1993, whereas profits pertain to center profits of the previous fiscal year, PROFIT-EC is predetermined in Equation (1). To the extent that profits and the error term of the wage equation are not correlated over time, simultaneity should not be a problem. It should also be noted that deflating total profits by the number of workers (instead of worker hours) did not change the results. Table 2 shows that profits per hour of worker do not influence teacher wages, but they have a small positive impact on the wages of aides, with an elasticity of $0.01 .^{10}$

There is more than one interpretation of the coefficients of SERVICE WAGE, and PROFIT-EC. Within the framework of a bargaining model as described by Blanchlower, Oswald and Sanfey (1996) and Oswald (1982) (presented in the Appendix), where supernormal profits are shared between workers and the employer, wages depend not only on worker and firm characteristics, but also on profits, outside wage available to workers and the relative bargaining strength of the workers. Thus, alternative wages of the workers, represented by SERVICE WAGE, and profits per worker should be positively related to wages, while there should be an inverse relationship between wages and the area unemployment rate in a bargaining model.

${ }^{10}$ Estevao and Tevlin (1995) find that the elasticity is much higher in U.S. manufacturing if the profits are instrumented with demand shifters. 
In a strictly competitive model, there should not be a relationship between wages and firm's profits. However, within the framework of Blanchflower and Oswald (1994 p. 86) and Hildreth and Oswald (1997, p.333), a positive relationship between profits and wages may also emerge in a competitive framework with an upward sloping labor supply function. Along the same lines, Blanchflower and Oswald (1994) show that the positive relationship between profitability-per-employee and the wage holds as long as the demand for labor is less than unity (which is the case for child care centers as shown by Mocan 1997). There is a competitive explanation for the effect of the service sector wage as well. For example, an increase in the average service sector wage could be associated with an upward shift in the supply of child care labor, which would create an increase in child care workers' wages. As far as the wageunemployment association is concerned, the standard competitive framework suggests a positive relationship between the two, while a negative relationship may call for non-competitive explanations (Blanchflower and Oswald 1994, Chapter 3).

Panels A, B and C of Table 2 suggest that wage determination processes of teachers and aides are governed by different mechanisms. The competitive model seems to be more relevant for teachers' wages. This is because profits of the firm per hour of labor has no impact on the wages of teachers, and the positive impacts of the service wage and the local unemployment rate have simple competitive explanations. On the other hand for aides, the fact that all three variables are significant with signs consistent with non-competitive scenarios gives support to non-competitive wage determination. 


\section{Center Characteristics}

The influence of center characteristics on wages are presented in Panel D of Table 2. In agreement with previous studies on firm size, the coefficient of FTE-CHILDREN is positive and significant in teacher regressions, indicating a positive impact of the center size on teacher wages. This result is interesting, because our model controls for a host of firm and worker characteristics, and yet the size-wage relationship persists. Mocan (1997) reports evidence for economies of scale in the production of child care services. But the size of the center (FTECHILDREN) is not likely to proxy this scale effect, because scale economies would ultimately impact the profits, which are included in the model.

It is important to note that the size of the center is positive and significant in teacher wage regressions, but it has no impact on aides' wages. These two pieces of information lend support to a monitoring-shirking based efficiency wage hypothesis. Aides work with teachers in a given classroom and they are supervised by teachers. Regardless of the size of the center, the relevant job environment where aides can be observed and supervised is the classroom.

Given that they work in a room with at least one supervisor (teacher), the size of the center has no relevance on the effort level of the aides. On the other hand, teachers are supervised by the director(s) of the center, who have limited opportunity to observe the teachers in the classroom. As the size of the center goes up, it becomes more difficult for the director to supervise the teachers. Thus, the positive teacher wage-size relationship may be attributable to the efficiency wages paid to teachers (but not to aides) to prevent shirking. 
The presence of a written salary schedule (WRSAL) is positively associated with both teacher and aide wages. The presence of a before and after school care program for school-agers reduces teacher wages by 6 percent.

The coefficient of PRODUCTIVITY is positive and significant in teacher regression, but insignificant in aide regression, although the point estimates are similar to each other. The average quality of the services provided by the centers (which is the dependent variable of Equation 2) is 4.0 on a scale from 1 to 7 indicating mediocre quality, while a score of 5 represents good quality." This means that if the unobserved worker quality (which is the residual of Equation 2) goes up by one unit, this would bring an average center's quality from mediocre to good, and it is associated with a 2 percent increase in teacher wages. This is not a serious premium for a substantial increase in productivity.

Table 3 summarizes the findings of the wage regression reported in Table 2. In the interest of space we present only the impact of sector, insideroutsiders, human capital characteristics and race.

\section{Compensation}

Table 4 reports the results of the regressions where the dependent variables are hourly compensation of teachers and aides. Compensation is the sum of hourly wage and nonwage benefits. The creation of the compensation variable is described in the Appendix.

Because it includes the value of nonwage benefits, this is a better measure of worker remuneration. The disadvantage is the possibility of creating

11 See Mocan (1997) for a discussion. 
measurement error in the dependent variable, which would reduce the precision of the estimates.

The results are consistent with those of the wage regressions, although there are some differences. The race effects are not significant in compensation regressions, though the point estimates are similar to those obtained from wage regressions. The same is true for the unemployment rate and the service wage, which suggests that the coefficients are estimated with less precision than the ones of the wage regressions.

Unionization increases teacher and aide compensation by 26 percent and 33 percent, respectively, while the corresponding impacts were 19 percent and 16 percent for wages. This suggests that unionization has relatively more impact on non-wage benefits for aides.

Unobserved productivity is positive and statistically significant in both teacher and aide regressions, suggesting that an increase in unobserved worker productivity enough to bring a center from "mediocre" to "good" is associated with 3 percent higher compensation for teachers and 5 percent more compensation for aides.

\section{SUMMARY}

The existence of inter-industry and intra-industry wage differentials are considered as evidence in favor of non-competitive wage determination. However, objections to the previous empirical work can be raised on the grounds that many studies could not control for detailed worker and firm characteristics, and therefore wage differentials could be the reflection of omitted variables. In this paper we exploit the extraordinary detail of a new data set obtained from 398 
child care centers from California, Colorado, Connecticut and North Carolina. By focusing on a particular segment of one industry, we avoid issues related to unobservable inter-industry differentials. We investigate the determinants of wages and compensation at the center level for both teachers and aides by employing more than 50 firm and worker attributes. Our data set also enables us to create a proxy for unobserved productivity.

Earlier theoretical and empirical literature suggested a wage-premium associated with nonprofit segment of the industry. Estimation of wage equations by classifying centers into for-profit and nonprofit categories supports this hypothesis. However, when we further classify the centers within each sector (e.g. publicly supported nonprofit, religious nonprofit, local for-profit, etc.) we find that nonprofit status has no impact on wages per se, but certain subcategories of the nonprofit sector have a significant influence on wages. These influences are different between occupations (teachers and aides). They also depend on the racial composition of the staff within occupations. As an example, we find that aides' wages in publicly supported nonprofit centers are not different from aides' wages in other types of centers. However, these centers pay a wage premium to teachers in comparison to other centers. Furthermore, this premium is a function of the racial composition of aides at the centers. If all teachers in a publicly supported center are non-white the premium is zero; if all aides are white, their wages are 13 percent lower. Similar relationships hold in some other sub-sectors of the nonprofit sector. For example, publicly owned and operated centers pay wage premiums to both aides and teachers, and the premium is higher the higher the proportion of minority staff. These results, which are summarized in Table 3, demonstrate that the extent of the wage premium enjoyed by nonprofit 
workers depends on the category of nonprofit center, occupation of the workers, and their race. This suggests that the distribution of these rents depend on the objective of the firm, that goes beyond a simple nonprofit affiliation. For example, the results clearly suggest that nonprofit centers that are owned or supported by the government create rents that go in the direction of minority workers; whereas religious nonprofit centers and nonprofit centers where the funding is tied to special regulations pay wage premiums to white workers. It is not easy to attribute these wage premiums to worker quality, because in addition to a long list of observable worker characteristics, unobservable worker quality is also controlled for. The race effects are not statistically significant in compensation regressions, possibly because of the measurement error in compensation.

These results are important for a variety of reasons. They document, for the first time, the presence of a race premium as a function of ownership. Second, they indicate that the premium varies between occupations (teachers vs. aides) within a narrowly defined industry. Third, they show that concerns regarding the behavioral differences between non-profit and for-profit sectors are not valid, at least in the context of the center-based segment of the child care industry; but research focus should be directed towards intra-sector variations.

The rate of return to an additional year of tenure is around 2 percent for both teachers and aides. The return to an additional year of prior experience is approximately 1 percent for teachers and zero for aides. An additional year of general education brings about a 5 percent increase in teacher wages, and a 2.6 percent increase in aides' wages. Similarly, specialized training influences teacher wages, but has less impact on aide wages. To the extent that the child 
care industry is secondary labor market, these differences in returns to education and skill suggest the presence of a secondary market within a secondary market. Alternatively, as we suggest in the paper, they may be a natural reaction of centers to apparently low productivity of aides shown elsewhere (Krueger 1997, Blau 1997a). Unobserved productivity, which is related to the quality of the services produced, has a small positive impact on teacher wages and teacher and aide compensation.

We find that unionization has a large impact on both wages and compensation of teachers and aides. The presence of a union increases teacher wages by 19 percent and aide wages by 17 percent. The corresponding increases for compensation are 26 percent and 33 percent, respectively, for teachers and aides. Alternative wages of the workers, proxied by the average service sector wages in the county where the center is located, are positively related to teacher and aide wages. An increase in local unemployment decreases aides' wages, but has a positive impact on the wages of teachers. We also find evidence of profit sharing in the case of aides: an increase in the previous year's profits is associated with an increase in aides' wages in the current year. Profits do not have an impact on teacher wages.

We find that an increase in center size, measured by full-time equivalent children, positively impacts wages of teachers, but has no influence on aides' wages. This result supports an efficiency wage hypothesis related to shirking. This is because center size has no relevance in monitoring the performance of aides, who are supervised by teachers in a given classroom. On the other hand, as the size of the center goes up, it becomes more difficult to monitor the teachers, who are supervised by center directors. 
This body of evidence indicates both teacher and aide remuneration have non-competitive flavors. The case is more compelling for aides. For teachers, with the exception of the shirking-related efficiency wages argument, a competitive labor market might not be a bad approximation. 
Table 1

Descriptive Statistics

\begin{tabular}{|c|c|c|c|c|c|}
\hline Variable & $\begin{array}{l}\text { NonP: } \\
(N=1\end{array}$ & $\begin{array}{l}\text { rofit Fo } \\
\text { 198) }\end{array}$ & $\begin{array}{l}\text { or-profit } \\
(\mathrm{N}=201)\end{array}$ & $\begin{array}{c}\text { All } \\
(N=399)\end{array}$ & $\begin{array}{l}\text { State } \\
\text { Diffs }\end{array}$ \\
\hline \multicolumn{6}{|c|}{ A. Wages and Compensation } \\
\hline TEACHER-WAGE* & $\begin{array}{l}\text { Center average wage for } \\
\text { teachers (weighted by hours } \\
\text { worked). }\end{array}$ & $\begin{array}{c}8.293 \\
(3.352)\end{array}$ & $\begin{array}{l}6.775 \\
(1.807)\end{array}$ & $\begin{array}{l}7.5307 \\
(2.791)\end{array}$ & $\begin{array}{l}\mathrm{CA}, \mathrm{CO}, \\
\mathrm{CT}, \mathrm{NC}\end{array}$ \\
\hline TEACHER-COMP* & $\begin{array}{l}\text { Average teacher } \\
\text { compensation. }\end{array}$ & $\begin{array}{l}10.276 \\
(5.020)\end{array}$ & $\begin{array}{c}7.973 \\
(2.623)\end{array}$ & $\begin{array}{l}9.101 \\
(4.055)\end{array}$ & $\begin{array}{l}\mathrm{CA}, \mathrm{CO} \\
\mathrm{CT}, \mathrm{NC}\end{array}$ \\
\hline AIDE-WAGE* & $\begin{array}{l}\text { Center average wage for } \\
\text { aides (weighted by hours } \\
\text { worked). }\end{array}$ & $\begin{array}{c}6.079 \\
(1.630)\end{array}$ & $\begin{array}{c}5.441 \\
(1.120)\end{array}$ & $\begin{array}{c}5.773 \\
(1.442)\end{array}$ & $\begin{array}{l}\mathrm{CO}, \mathrm{CT} \\
\mathrm{NC}\end{array}$ \\
\hline AIDE-COMP* & $\begin{array}{l}\text { Average aide } \\
\text { compensation. }\end{array}$ & $\begin{array}{c}7.529 \\
(3.099)\end{array}$ & $\begin{array}{c}6.198 \\
(1.490)\end{array}$ & $\begin{array}{c}6.894 \\
(2.549)\end{array}$ & $\begin{array}{l}\mathrm{CO}, \mathrm{CT} \\
\mathrm{NC}\end{array}$ \\
\hline \multicolumn{6}{|c|}{ B. Insider-Outsider and Center Characteristics } \\
\hline SERVICE WAGE & $\begin{array}{l}\text { Average county service } \\
\text { industry wage, } 1993 .\end{array}$ & $\begin{array}{l}13.382 \\
(2.891)\end{array}$ & $\begin{array}{l}13.316 \\
(2.697)\end{array}$ & $\begin{array}{l}13.349 \\
(2.791)\end{array}$ & $\mathrm{CO}, \mathrm{NC}$ \\
\hline UNEMP RATE* & $\begin{array}{l}\text { Average county } \\
\text { unemployment rate, } 1993 .\end{array}$ & $\begin{array}{c}6.638 \\
(2.379)\end{array}$ & $\begin{array}{c}6.036 \\
(1.895)\end{array}$ & $\begin{array}{c}6.333 \\
(2.166)\end{array}$ & $\begin{array}{l}\mathrm{CT}, \mathrm{CO}, \\
\mathrm{CA}\end{array}$ \\
\hline PROFIT-AC* & $\begin{array}{l}\text { Center accounting profit } \\
\text { per hour of labor } \\
\text { employed. }\end{array}$ & $\begin{array}{c}0.421 \\
(2.087)\end{array}$ & $\begin{array}{c}0.861 \\
(2.172)\end{array}$ & $\begin{array}{c}0.643 \\
(2.139)\end{array}$ & $\mathrm{CA}$ \\
\hline PROFIT-EC & $\begin{array}{l}\text { Center economic profit per } \\
\text { hour of labor employed. }\end{array}$ & $\begin{array}{c}0.900 \\
(2.296)\end{array}$ & $\begin{array}{l}0.610 \\
(2.114)\end{array}$ & $\begin{array}{c}0.753 \\
(2.208)\end{array}$ & $\mathrm{CO}, \mathrm{CT}$ \\
\hline QUALITY* & $\begin{array}{l}\text { Center process quality } \\
\text { index. }\end{array}$ & $\begin{array}{l}4.145 \\
(0.831)\end{array}$ & $\begin{array}{c}3.871 \\
(0.851)\end{array}$ & $\begin{array}{c}4.006 \\
(0.851)\end{array}$ & $\mathrm{NC}$ \\
\hline PRODUCTIVITY & $\begin{array}{l}\text { Unobserved Center } \\
\text { Productivity ( } \nu \text { in Equations } \\
1 \text { and 2) }\end{array}$ & $\begin{array}{l}0.000^{\mathrm{a}} \\
(0.658)\end{array}$ & $\begin{array}{l}0.000^{2} \\
(0.643)\end{array}$ & $\begin{array}{l}0.000^{2} \\
(0.650)\end{array}$ & $\mathrm{CT}, \mathrm{NC}$ \\
\hline UNION & $\begin{array}{l}\text { Dummy variable }(=1) \text { if } \\
\text { center workers are } \\
\text { unionized. }\end{array}$ & $\begin{array}{c}0.091 \\
(0.289)\end{array}$ & & $\begin{array}{c}0.046 \\
(0.209)\end{array}$ & \\
\hline PUBLIC-AUSPICE & $\begin{array}{l}\text { Dummy variable }(=1) \text { if } \\
\text { center is publicly owned } \\
\text { and operated, }(=0) \\
\text { otherwise. }\end{array}$ & $\begin{array}{c}0.136 \\
(0.344)\end{array}$ & & $\begin{array}{c}0.068 \\
(0.251)\end{array}$ & \\
\hline $\begin{array}{l}\text { PUBLIC- } \\
\text { SUPPORT* }\end{array}$ & $\begin{array}{l}\text { Dummy variable }(=1) \text { if center } \\
\text { is not publicly owned or } \\
\text { operated, but receives more } \\
\text { than } 50 \text { percent of its revenue } \\
\text { from public grants, fees and } \\
\text { USDA reimbursement, }(=0) \\
\text { otherwise. }\end{array}$ & $\begin{array}{c}0.192 \\
(0.395)\end{array}$ & $\begin{array}{c}0.040 \\
(0.196)\end{array}$ & $\begin{array}{l}0.115 \\
(0.320)\end{array}$ & $\mathrm{CO}, \mathrm{NC}$ \\
\hline
\end{tabular}


(Table 1 continued)

\begin{tabular}{|c|c|c|c|c|c|}
\hline Variable & Definition & $\begin{array}{l}\text { Nonprofit } \\
(\mathrm{N}=198)\end{array}$ & $\begin{array}{c}\text { For- } \\
\text { profit } \\
(\mathrm{N}=201)\end{array}$ & $\begin{array}{c}\text { All } \\
(\mathrm{N}=399)\end{array}$ & $\begin{array}{l}\text { State } \\
\text { Diffs }\end{array}$ \\
\hline $\begin{array}{l}\text { SPECIAL } \\
\text { REGUL }\end{array}$ & $\begin{array}{l}\text { Dummy variable }(=1) \text { if } \\
\text { center receives public } \\
\text { money tied to higher } \\
\text { standards, }(=0) \text { otherwise. }\end{array}$ & $\begin{array}{l}0.141 \\
(0.349)\end{array}$ & 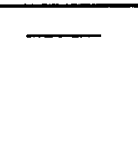 & $\begin{array}{l}0.070 \\
(0.256)\end{array}$ & \\
\hline RELIGIOUS & $\begin{array}{l}\text { Dummy variable }(=1) \text { if } \\
\text { center is religiously } \\
\text { affiliated, }(=0) \text { otherwise. }\end{array}$ & $\begin{array}{c}0.394 \\
(0.490)\end{array}$ & . & $\begin{array}{c}0.195 \\
(0.397)\end{array}$ & \\
\hline FOR-PROFIT & $\begin{array}{l}\text { Dummy variable }(=1) \text { if } \\
\text { center is for-profit, }(=0) \\
\text { otherwise. }\end{array}$ & & $\begin{array}{c}1.000 \\
(0.000)\end{array}$ & $\begin{array}{c}0.504 \\
(0.501)\end{array}$ & \\
\hline ONSITE & $\begin{array}{l}\text { Dummy variable }(=1) \text { if } \\
\text { center is a worksite child } \\
\text { care center. }\end{array}$ & $\begin{array}{c}0.056 \\
(0.230)\end{array}$ & $\begin{array}{c}0.020 \\
(0.140)\end{array}$ & $\begin{array}{c}0.038 \\
(0.190)\end{array}$ & \\
\hline $\begin{array}{l}\text { NATIONAL } \\
\text { CHAIN }\end{array}$ & $\begin{array}{l}\text { Dummy variable }(=1) \text { if } \\
\text { center is member of a } \\
\text { national chain. }\end{array}$ & & $\begin{array}{c}0.239 \\
(0.427)\end{array}$ & $\begin{array}{c}0.120 \\
(0.326)\end{array}$ & \\
\hline RATIO* & $\begin{array}{l}\text { The weighted prime time } \\
\text { staff-child ratio. }\end{array}$ & $\begin{array}{c}0.187 \\
(0.086)\end{array}$ & $\begin{array}{c}0.161 \\
(0.075)\end{array}$ & $\begin{array}{c}0.175 \\
(0.084)\end{array}$ & $\mathrm{CA}, \mathrm{NC}$ \\
\hline GROUP & $\begin{array}{l}\text { The weighted prime time } \\
\text { group size. }\end{array}$ & $\begin{array}{l}13.167 \\
(5.014)\end{array}$ & $\begin{array}{l}12.882 \\
(6.534)\end{array}$ & $\begin{array}{l}13.002 \\
(5.817)\end{array}$ & \\
\hline SUBSIDIZED* & $\begin{array}{l}\text { The proportion of children } \\
\text { that are subsidized. }\end{array}$ & $\begin{array}{c}0.337 \\
(0.391)\end{array}$ & $\begin{array}{c}0.127 \\
(0.169)\end{array}$ & $\begin{array}{c}0.231 \\
(0.318)\end{array}$ & $\begin{array}{l}\mathrm{CA}, \\
\mathrm{NC}, \\
\mathrm{CO}, \mathrm{CT}\end{array}$ \\
\hline WHITE & The proportion of white & 0.601 & 0.760 & 0.683 & CT, \\
\hline CHILDRN* & children at the center. & & $(.246)$ & $(.312)$ & $\mathrm{CO}, \mathrm{CA}$ \\
\hline $\begin{array}{l}\text { INFANT- } \\
\text { RATIO* }\end{array}$ & $\begin{array}{l}\text { The proportion of infants at } \\
\text { the center. }\end{array}$ & $\begin{array}{c}0.175 \\
(0.225)\end{array}$ & $\begin{array}{c}0.251 \\
(0.231)\end{array}$ & $\begin{array}{c}0.213 \\
(0.231)\end{array}$ & $\mathrm{CT}, \mathrm{NC}$ \\
\hline $\begin{array}{l}\text { PRESCH- } \\
\text { RATIO* }\end{array}$ & $\begin{array}{l}\text { The proportion of } \\
\text { preschoolers at the center. }\end{array}$ & $\begin{array}{c}0.674 \\
(0.253)\end{array}$ & $\begin{array}{c}0.538 \\
(0.236)\end{array}$ & $\begin{array}{c}0.606 \\
(0.254)\end{array}$ & $\begin{array}{l}\mathrm{NC}, \\
\mathrm{CO}, \mathrm{CT}\end{array}$ \\
\hline CENTER & Number of years that & 16.279 & 10.265 & 13.280 & CT, \\
\hline $\mathrm{AGE}^{*}$ & $\begin{array}{l}\text { center has been in } \\
\text { operation. }\end{array}$ & $(14.717)$ & $(8.314)$ & $(12.319)$ & $\mathrm{CO}, \mathrm{NC}$ \\
\hline $\begin{array}{l}\text { FTE- } \\
\text { CHILDREN* }\end{array}$ & $\begin{array}{l}\text { Total FTE Children } \\
\text { Enrolled. }\end{array}$ & $\begin{array}{c}60.427 \\
(39.672)\end{array}$ & $\begin{array}{c}75.972 \\
(51.726)\end{array}$ & $\begin{array}{c}68.258 \\
(46.734)\end{array}$ & $\mathrm{CA}, \mathrm{CO}$ \\
\hline $\begin{array}{l}\text { TEACHER- } \\
\text { WHITE* }\end{array}$ & $\begin{array}{l}\text { Weighted percentage of } \\
\text { white teachers. }\end{array}$ & $\begin{array}{c}0.633 \\
(0.395)\end{array}$ & $\begin{array}{c}0.749 \\
(0.321)\end{array}$ & $\begin{array}{c}0.691 \\
(0.364)\end{array}$ & $\begin{array}{l}\mathrm{CO}, \\
\mathrm{CT}, \mathrm{NC}\end{array}$ \\
\hline AIDE-WHITE* & $\begin{array}{l}\text { Weighted percentage of } \\
\text { white aides. }\end{array}$ & $\begin{array}{c}0.454 \\
(0.424)\end{array}$ & $\begin{array}{c}0.730 \\
(0.387)\end{array}$ & $\begin{array}{c}0.586 \\
(0.428)\end{array}$ & $\begin{array}{l}\mathrm{CA}, \\
\mathrm{CO}, \mathrm{CT}\end{array}$ \\
\hline WRJOB-T* & $\begin{array}{l}\text { Dummy }(=1) \text { if center } \\
\text { provides written job } \\
\text { description for teachers. }\end{array}$ & $\begin{array}{c}0.954 \\
(0.209)\end{array}$ & $\begin{array}{c}0.900 \\
(0.300)\end{array}$ & $\begin{array}{c}0.927 \\
(0.260)\end{array}$ & $\mathrm{NC}$ \\
\hline
\end{tabular}


(Table 1 continued)

\begin{tabular}{|c|c|c|c|c|c|}
\hline Variable & Definition & $\begin{array}{l}\text { Nonprofit } \\
(N=198)\end{array}$ & $\begin{array}{c}\text { For- } \\
\text { profit } \\
(\mathrm{N}=\mathbf{2 0 1})\end{array}$ & $\begin{array}{c}\text { All } \\
(\mathrm{N}=399)\end{array}$ & $\begin{array}{l}\text { State } \\
\text { Diffs }\end{array}$ \\
\hline WRCONTR-T & $\begin{array}{l}\text { Dummy }(=1) \text { if center } \\
\text { provides written contract } \\
\text { for teachers. }\end{array}$ & $\begin{array}{l}0.416 \\
(0.494)\end{array}$ & $\begin{array}{c}0.338 \\
(0.474)\end{array}$ & $\begin{array}{l}0.377 \\
(0.485)\end{array}$ & \\
\hline WRSAL-T* & $\begin{array}{l}\text { Dummy }(=1) \text { if center } \\
\text { provides written salary } \\
\text { schedule for teachers. }\end{array}$ & $\begin{array}{c}0.604 \\
(0.490)\end{array}$ & $\begin{array}{c}0.289 \\
(0.454)\end{array}$ & $\begin{array}{c}0.445 \\
(0.498)\end{array}$ & $\begin{array}{l}\mathrm{CT} \\
\mathrm{CO} \\
\mathrm{NC}, \mathrm{CA}\end{array}$ \\
\hline WRJOB-A & $\begin{array}{l}\text { Dummy }(=1) \text { if center } \\
\text { provides written job } \\
\text { description for aides. }\end{array}$ & $\begin{array}{c}0.787 \\
(0.411)\end{array}$ & $\begin{array}{c}0.766 \\
(0.424)\end{array}$ & $\begin{array}{c}0.776 \\
(0.417)\end{array}$ & \\
\hline WRCONTR-A & $\begin{array}{l}\text { Dummy }(=1) \text { if center } \\
\text { provides written contract } \\
\text { for aides. }\end{array}$ & $\begin{array}{c}0.305 \\
(0.461)\end{array}$ & $\begin{array}{c}0.254 \\
(0.436)\end{array}$ & $\begin{array}{c}0.279 \\
(0.449)\end{array}$ & \\
\hline WRSAL-A* & $\begin{array}{l}\text { Dummy }(=1) \text { if center } \\
\text { provides written salary } \\
\text { schedule for aides. }\end{array}$ & $\begin{array}{c}0.487 \\
(0.501)\end{array}$ & $\begin{array}{c}0.239 \\
(0.427)\end{array}$ & $\begin{array}{c}0.362 \\
(0.481)\end{array}$ & $\begin{array}{l}\mathrm{CT}, \\
\mathrm{CO}, \mathrm{CA}\end{array}$ \\
\hline \multicolumn{6}{|c|}{ C. Center Programs } \\
\hline BEFORE-AFTER* & $\begin{array}{l}\text { Dummy }(=1) \text { if center } \\
\text { provides before and after } \\
\text { school care. }\end{array}$ & $\begin{array}{c}0.472 \\
(0.500)\end{array}$ & $\begin{array}{l}0.721 \\
(0.449)\end{array}$ & $\begin{array}{ll}0.598 & c \\
(0.491) & \mathrm{N}\end{array}$ & $\begin{array}{l}\mathrm{CT}, \mathrm{CO}, \\
\mathrm{NC}\end{array}$ \\
\hline WEEKEND & $\begin{array}{l}\text { Dummy }(=1) \text { if center } \\
\text { provides a weekend care } \\
\text { program. }\end{array}$ & $\begin{array}{c}0.015 \\
(0.123)\end{array}$ & $\begin{array}{c}0.035 \\
(0.184)\end{array}$ & $\begin{array}{c}0.025 \\
(0.157)\end{array}$ & \\
\hline PARTDAY* & $\begin{array}{l}\text { Dummy }(=1) \text { if part-day } \\
\text { program. }\end{array}$ & $\begin{array}{c}0.695 \\
(0.461)\end{array}$ & $\begin{array}{c}0.871 \\
(0.336)\end{array}$ & $\begin{array}{c}0.784 \\
(0.412)\end{array}$ & $\begin{array}{l}\mathrm{CO}, \mathrm{CT}, \\
\mathrm{NC}\end{array}$ \\
\hline PRTDAYEX* & $\begin{array}{l}\text { Dummy }(=1) \text { if part-day } \\
\text { extended care program. }\end{array}$ & $\begin{array}{c}0.442 \\
(0.498)\end{array}$ & $\begin{array}{c}0.682 \\
(0.467)\end{array}$ & $\begin{array}{c}0.563 \\
(0.497)\end{array}$ & $\begin{array}{l}\mathrm{CA}, \mathrm{CO}, \\
\mathrm{CT}\end{array}$ \\
\hline HEADSTART & $\begin{array}{l}\text { Dummy }(=1) \text { if the center } \\
\text { is a Head Start program. }\end{array}$ & $\begin{array}{c}0.041 \\
(0.198)\end{array}$ & & $\begin{array}{c}0.020 \\
(0.141)\end{array}$ & \\
\hline \multicolumn{6}{|c|}{ D. Human Capital Characteristics: Teachers } \\
\hline $\mathrm{AGE}^{*}$ & $\begin{array}{l}\text { Average teacher age } \\
\text { weighted by hours worked. }\end{array}$ & $\begin{array}{l}36.815 \\
(7.662)\end{array}$ & $\begin{array}{l}32.990 \\
(6.520)\end{array}$ & $\begin{array}{l}34.888 \\
(7.354)\end{array}$ & $\begin{array}{l}\overline{\mathrm{CA}}, \mathrm{CO} \\
\mathrm{CT}, \mathrm{NC}\end{array}$ \\
\hline EXPERIENCE* & $\begin{array}{l}\text { Average teacher prior child } \\
\text { care experience weighted } \\
\text { by hours worked. }\end{array}$ & $\begin{array}{c}4.803 \\
(3.806)\end{array}$ & $\begin{array}{l}3.703 \\
(3.003)\end{array}$ & $\begin{array}{c}4.254 \\
(3.469)\end{array}$ & $\mathrm{CO}$ \\
\hline TENURE* & $\begin{array}{l}\text { Average teacher tenure (in } \\
\text { months) weighted by hours } \\
\text { worked. }\end{array}$ & $\begin{array}{l}4.968 \\
(3.896)\end{array}$ & $\begin{array}{l}3.046 \\
(2.287)\end{array}$ & $\begin{array}{c}4.003 \\
(3.328)\end{array}$ & $\begin{array}{l}\mathrm{CA}, \mathrm{CO} \\
\mathrm{CT}, \mathrm{NC}\end{array}$ \\
\hline
\end{tabular}


(Table 1 continued)

\begin{tabular}{|c|c|c|c|c|c|}
\hline Variable & Definition & $\begin{array}{l}\text { Nonprofit } \\
(\mathrm{N}=198)\end{array}$ & $\begin{array}{c}\text { For- } \\
\text { profit } \\
(\mathrm{N}=\mathbf{2 0 1})\end{array}$ & $\begin{array}{c}\text { All } \\
(N=399)\end{array}$ & $\begin{array}{l}\text { State } \\
\text { Diffs }\end{array}$ \\
\hline EDUCATION* & Average teacher education. & $\begin{array}{l}14.515 \\
(1.399)\end{array}$ & $\begin{array}{l}14.002 \\
(1.345)\end{array}$ & $\begin{array}{l}14.257 \\
(1.394)\end{array}$ & $\begin{array}{l}\mathrm{CO}, \\
\mathrm{CT}, \mathrm{NC}\end{array}$ \\
\hline T-NOHIGHSCH & $\begin{array}{l}\text { Percentage of teachers with } \\
\text { less than high school } \\
\text { education }\end{array}$ & $\begin{array}{c}0.005 \\
(0.031)\end{array}$ & $\begin{array}{l}0.0063 \\
(0.035)\end{array}$ & $\begin{array}{l}0.0056 \\
(0.033)\end{array}$ & \\
\hline T-HIGHSCH* & $\begin{array}{l}\text { Percentage of teachers with } \\
\text { a high school education }\end{array}$ & $\begin{array}{l}0.224 \\
(0.297)\end{array}$ & $\begin{array}{c}0.321 \\
(0.329)\end{array}$ & $\begin{array}{c}0.224 \\
(0.297)\end{array}$ & $\mathrm{NC}$ \\
\hline T-SOMECOLL & $\begin{array}{l}\text { Percentage of teachers with } \\
\text { some college }\end{array}$ & $\begin{array}{c}0.360 \\
(0.312)\end{array}$ & $\begin{array}{c}0.356 \\
(0.311)\end{array}$ & $\begin{array}{l}0.358 \\
(0.311)\end{array}$ & $\mathrm{NC}$ \\
\hline T-COLLEGE & $\begin{array}{l}\text { Percentage of teachers with } \\
\text { a college degree }\end{array}$ & $\begin{array}{c}0.284 \\
(0.280)\end{array}$ & $\begin{array}{l}0.263 \\
(0.299)\end{array}$ & $\begin{array}{c}0.273 \\
(0.290)\end{array}$ & $\mathrm{NC}$ \\
\hline T-POSTCOLL* & $\begin{array}{l}\text { Percentage of teachers with } \\
\text { post college degree }\end{array}$ & $\begin{array}{c}0.127 \\
(0.243)\end{array}$ & $\begin{array}{c}0.054 \\
(0.153)\end{array}$ & $\begin{array}{l}0.090 \\
(0.205)\end{array}$ & $\mathrm{CO}, \mathrm{CT}$ \\
\hline NOTRAINING* & $\begin{array}{l}\text { Teacher hours with no } \\
\text { training as a \% of total } \\
\text { teacher hours. }\end{array}$ & $\begin{array}{c}0.019 \\
(0.091)\end{array}$ & $\begin{array}{c}0.058 \\
(0.169)\end{array}$ & $\begin{array}{c}0.039 \\
(0.137)\end{array}$ & $\mathrm{CO}, \mathrm{CT}$ \\
\hline TRAINING-2* & $\begin{array}{l}\text { Teachers hours of training } \\
\text { in in-service workshops at } \\
\text { the center as a \% of total } \\
\text { teacher hours. }\end{array}$ & $\begin{array}{c}0.670 \\
(0.456)\end{array}$ & $\begin{array}{c}0.559 \\
(0.472)\end{array}$ & $\begin{array}{c}0.614 \\
(0.467)\end{array}$ & $\mathrm{CA}, \mathrm{NC}$ \\
\hline TRAINING-3* & $\begin{array}{l}\text { Teacher hours of training } \\
\text { in community workshops or } \\
\text { at professional meetings as } \\
\text { a \% of total teacher hours. }\end{array}$ & $\begin{array}{c}0.691 \\
(0.421)\end{array}$ & $\begin{array}{c}0.561 \\
(0.462)\end{array}$ & $\begin{array}{c}0.626 \\
(0.446)\end{array}$ & $\mathrm{CO}, \mathrm{NC}$ \\
\hline TRAINING-4* & $\begin{array}{l}\text { Teacher hours of training } \\
\text { in high school or vocational } \\
\text { school as a \% of total } \\
\text { teacher hours. }\end{array}$ & $\begin{array}{c}0.064 \\
(0.201)\end{array}$ & $\begin{array}{c}0.112 \\
(0.250)\end{array}$ & $\begin{array}{c}0.088 \\
(0.228)\end{array}$ & $\mathrm{CT}, \mathrm{NC}$ \\
\hline TRAINING-5 & $\begin{array}{l}\text { Teacher hours of CDA } \\
\text { training in early child care } \\
\text { as a \% of total teacher } \\
\text { hours. }\end{array}$ & $\begin{array}{c}0.082 \\
(0.211)\end{array}$ & $\begin{array}{c}0.061 \\
(0.183)\end{array}$ & $\begin{array}{c}0.434 \\
(0.378)\end{array}$ & $\mathrm{NC}$ \\
\hline TRAINING-6 & $\begin{array}{l}\text { Teacher hours of courses } \\
\text { at a community college or } \\
\text { four year college as a } \% \text { of } \\
\text { total teacher hours. }\end{array}$ & $\begin{array}{c}0.445 \\
(0.389)\end{array}$ & $\begin{array}{c}0.423 \\
(0.368)\end{array}$ & $\begin{array}{c}0.072 \\
(0.198)\end{array}$ & \\
\hline TRAINING-7* & $\begin{array}{l}\text { Teacher hours in AA } \\
\text { training in early child care } \\
\text { as a } \% \text { of total teacher } \\
\text { hours. }\end{array}$ & $\begin{array}{l}0.177 \\
(0.251)\end{array}$ & $\begin{array}{c}0.123 \\
(0.206)\end{array}$ & $\begin{array}{c}0.150 \\
(0.231)\end{array}$ & NC \\
\hline
\end{tabular}


(Table 1 continued)

\begin{tabular}{|c|c|c|c|c|c|}
\hline Variable & Definition & $\begin{array}{l}\text { Nonprofit } \\
(\mathrm{N}=198)\end{array}$ & $\begin{array}{c}\text { For- } \\
\text { profit } \\
(\mathrm{N}=201)\end{array}$ & $\begin{array}{c}\text { All } \\
(\mathrm{N}=399)\end{array}$ & $\begin{array}{l}\text { State } \\
\text { Diffs }\end{array}$ \\
\hline TRAINING-8 & $\begin{array}{l}\text { Teacher hours training as } \\
\text { R. N. as a \% of total } \\
\text { teacher hours. }\end{array}$ & $\begin{array}{l}0.005 \\
(0.032)\end{array}$ & $\begin{array}{l}0.004 \\
(0.031)\end{array}$ & $\begin{array}{l}0.004 \\
(0.031)\end{array}$ & $\mathrm{NC}$ \\
\hline TRAINING-9* & $\begin{array}{l}\text { Teacher hours with a } \\
\text { BA/BS in ECE, child } \\
\text { development, nursing, } \\
\text { education, etc. as a \% of } \\
\text { total teacher hours. }\end{array}$ & $\begin{array}{c}0.327 \\
(0.325)\end{array}$ & $\begin{array}{c}0.251 \\
(0.306)\end{array}$ & $\begin{array}{c}0.289 \\
(0.317)\end{array}$ & NC \\
\hline TRAINING-10* & $\begin{array}{l}\text { Ratio of teachers with } \\
\text { graduate level courses. } \\
\text { (weighted average) }\end{array}$ & $\begin{array}{l}0.108 \\
(0.215)\end{array}$ & $\begin{array}{c}0.019 \\
(0.091)\end{array}$ & $\begin{array}{l}0.063 \\
(0.170)\end{array}$ & $\begin{array}{l}\mathrm{CA} \\
\mathrm{CO} \\
\mathrm{CT}, \mathrm{NC}\end{array}$ \\
\hline TRAINING-11* & $\begin{array}{l}\text { Ratio of teachers with a } \\
\text { graduate degree in ECE, } \\
\text { child development, etc. } \\
\text { (weighted average) }\end{array}$ & $\begin{array}{c}0.068 \\
(0.190)\end{array}$ & $\begin{array}{c}0.022 \\
(0.092)\end{array}$ & $\begin{array}{c}0.045 \\
(0.150)\end{array}$ & CT \\
\hline \multicolumn{6}{|c|}{ E. Human Capital Characteristics: Aides } \\
\hline$\overline{A G E^{*}}$ & $\begin{array}{l}\text { Average aide age weighted } \\
\text { by hours worked. }\end{array}$ & $\begin{array}{l}35.227 \\
(9.665)\end{array}$ & $\begin{array}{l}28.715 \\
(8.824)\end{array}$ & $\begin{array}{l}32.091 \\
(9.808)\end{array}$ & $\begin{array}{l}\mathrm{CO}, \mathrm{CT} \\
\mathrm{NC}\end{array}$ \\
\hline EXPERIENCE* & $\begin{array}{l}\text { Average aide prior child } \\
\text { care experience weighted } \\
\text { by hours worked. }\end{array}$ & $\begin{array}{c}2.411 \\
(3.035)\end{array}$ & $\begin{array}{c}1.483 \\
(1.999)\end{array}$ & $\begin{array}{c}1.965 \\
(2.625)\end{array}$ & $\begin{array}{l}\mathrm{CO}, \mathrm{CT}, \\
\mathrm{NC}\end{array}$ \\
\hline TENURE* & $\begin{array}{l}\text { Average aide tenure (in } \\
\text { months) weighted by hours } \\
\text { worked. }\end{array}$ & $\begin{array}{c}3.473 \\
(3.726)\end{array}$ & $\begin{array}{c}1.383 \\
(1.277)\end{array}$ & $\begin{array}{c}2.470 \\
(3.012)\end{array}$ & $\begin{array}{l}\mathrm{CA}, \mathrm{CO} \\
\mathrm{CT}, \mathrm{NC}\end{array}$ \\
\hline EDUCATION* & Average aide education. & $\begin{array}{l}12.741 \\
(1.342)\end{array}$ & $\begin{array}{l}13.094 \\
(1.177)\end{array}$ & $\begin{array}{l}12.910 \\
(1.275)\end{array}$ & $\mathrm{CA}, \mathrm{CT}$ \\
\hline A-NOHIGHSCH* & $\begin{array}{l}\text { Percentage of aides with } \\
\text { less than High School } \\
\text { education. }\end{array}$ & $\begin{array}{l}0.045 \\
(0.142)\end{array}$ & $\begin{array}{l}0.015 \\
(0.062)\end{array}$ & $\begin{array}{c}0.030 \\
(0.111)\end{array}$ & \\
\hline A-HIGHSCH & $\begin{array}{l}\text { Percentage of aides with a } \\
\text { High School education. }\end{array}$ & $\begin{array}{c}0.566 \\
(0.368)\end{array}$ & $\begin{array}{c}0.533 \\
(0.393)\end{array}$ & $\begin{array}{c}0.551 \\
(0.379)\end{array}$ & \\
\hline A-SOMECOLL & $\begin{array}{l}\text { Percentage of aides with } \\
\text { some college. }\end{array}$ & $\begin{array}{c}0.294 \\
(0.335)\end{array}$ & $\begin{array}{c}0.294 \\
(0.364)\end{array}$ & $\begin{array}{c}0.297 \\
(0.347)\end{array}$ & \\
\hline A-COLLEGE* & $\begin{array}{l}\text { Percentage of aides with a } \\
\text { college degree. }\end{array}$ & $\begin{array}{l}0.086 \\
(0.196)\end{array}$ & $\begin{array}{c}0.147 \\
(0.268)\end{array}$ & $\begin{array}{c}0.114 \\
(0.235)\end{array}$ & $\mathrm{CA}$ \\
\hline A-POSTCOLL & $\begin{array}{l}\text { Percentage of aides with } \\
\text { post college degree. }\end{array}$ & $\begin{array}{c}0.011 \\
(0.058)\end{array}$ & $\begin{array}{l}0.005 \\
(0.038)\end{array}$ & $\begin{array}{c}0.008 \\
(0.050)\end{array}$ & \\
\hline NOTRAINING & $\begin{array}{l}\text { Aide hours with have no } \\
\text { training as a \% of aide } \\
\text { hours. }\end{array}$ & $\begin{array}{c}0.151 \\
(0.312)\end{array}$ & $\begin{array}{c}0.187 \\
(0.329)\end{array}$ & $\begin{array}{c}0.168 \\
(0.320)\end{array}$ & $\mathrm{CA}$ \\
\hline
\end{tabular}


(Table 1 concluded)

\begin{tabular}{|c|c|c|c|c|c|}
\hline Variable & Definition & $\begin{array}{c}\text { Nonprofit } \\
(N=198)\end{array}$ & $\begin{array}{c}\text { For- } \\
\text { profit } \\
(\mathrm{N}=201)\end{array}$ & $\begin{array}{c}\text { All } \\
(N=399)\end{array}$ & $\begin{array}{l}\text { State } \\
\text { Diffs }\end{array}$ \\
\hline TRAINING-2* & $\begin{array}{l}\text { Aide hours of training in } \\
\text { in-service workshops at the } \\
\text { center as a } \% \text { of aide } \\
\text { hours. }\end{array}$ & $\begin{array}{c}0.653 \\
(0.460)\end{array}$ & $\begin{array}{c}0.500 \\
(0.473)\end{array}$ & $\begin{array}{c}0.580 \\
(0.472)\end{array}$ & $\mathrm{CA}, \mathrm{NC}$ \\
\hline TRAINING-3* & $\begin{array}{l}\text { Aide hours of training at } \\
\text { community workshops or at } \\
\text { professional meetings as a } \\
\% \text { of total aide hours. }\end{array}$ & $\begin{array}{c}0.643 \\
(0.440)\end{array}$ & $\begin{array}{c}0.453 \\
(0.468)\end{array}$ & $\begin{array}{c}0.552 \\
(0.463)\end{array}$ & $\mathrm{CA}$ \\
\hline TRAINING-4 & $\begin{array}{l}\text { Aide hours of training in } \\
\text { high school or vocational } \\
\text { school as a \% of total aide } \\
\text { hours. }\end{array}$ & $\begin{array}{l}0.085 \\
(0.240)\end{array}$ & $\begin{array}{c}0.135 \\
(0.287)\end{array}$ & $\begin{array}{c}0.109 \\
(0.264)\end{array}$ & \\
\hline TRAINING-5* & $\begin{array}{l}\text { Aide hours with CDA } \\
\text { training in early child care } \\
\text { as a \% of total aide hours. }\end{array}$ & $\begin{array}{c}0.054 \\
(0.182)\end{array}$ & $\begin{array}{c}0.018 \\
(0.130)\end{array}$ & $\begin{array}{c}0.037 \\
(0.160)\end{array}$ & NC \\
\hline TRAINING-6 & $\begin{array}{l}\text { Aide hours with courses at } \\
\text { a community college or } \\
\text { four year college as a \% of } \\
\text { total aide hours. }\end{array}$ & $\begin{array}{c}0.380 \\
(0.384)\end{array}$ & $\begin{array}{c}0.348 \\
(0.391)\end{array}$ & $\begin{array}{c}0.365 \\
(0.387)\end{array}$ & \\
\hline TRAINING-7* & $\begin{array}{l}\text { Aide hours with at least an } \\
\text { AA training in early child } \\
\text { care as a \% of total aide } \\
\text { hours. }\end{array}$ & $\begin{array}{c}0.081 \\
(0.213)\end{array}$ & $\begin{array}{c}0.035 \\
(0.123)\end{array}$ & $\begin{array}{c}0.059 \\
(0.177)\end{array}$ & $\mathrm{NC}$ \\
\hline TRAINING-8 & $\begin{array}{l}\text { Aide hours with } \mathrm{R} . \mathrm{N} \text {. } \\
\text { training as a \% of total } \\
\text { aide hours. }\end{array}$ & $\begin{array}{c}0.002 \\
(0.016)\end{array}$ & 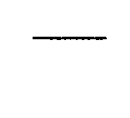 & $\begin{array}{c}0.001 \\
(0.012)\end{array}$ & \\
\hline TRAINING-9 & $\begin{array}{l}\text { Aide hours with a BA/BS } \\
\text { in ECE, child development, } \\
\text { nursing, education, etc. as } \\
\text { a \% of total aide hours. }\end{array}$ & $\begin{array}{c}0.079 \\
(0.206)\end{array}$ & $\begin{array}{c}0.107 \\
(0.246)\end{array}$ & $\begin{array}{c}0.093 \\
(0.226)\end{array}$ & \\
\hline TRAINING-10 & $\begin{array}{l}\text { Aide hours with graduate } \\
\text { level courses as a } \% \text { of } \\
\text { total aide hours. }\end{array}$ & $\begin{array}{c}0.009 \\
(0.052)\end{array}$ & $\begin{array}{c}0.002 \\
(0.019)\end{array}$ & $\begin{array}{c}0.006 \\
(0.040)\end{array}$ & \\
\hline TRAINING-11 & $\begin{array}{l}\text { Aide hours with a graduate } \\
\text { degree in ECE, child } \\
\text { development, etc. as a \% } \\
\text { of total aide hours. }\end{array}$ & $\begin{array}{c}0.015 \\
(0.099)\end{array}$ & $\begin{array}{c}0.013 \\
(0.126)\end{array}$ & $\begin{array}{c}0.014 \\
(0.112)\end{array}$ & \\
\hline
\end{tabular}

The entries are the means of the corresponding variable. The numbers in parencheses are the standard deviations.

* Indicares that the means are different at the 10 percent level. ' indicates a very small number. A state code in the last column indicates that the mean value of the corresponding variable is different between nonprofit and forprofit centers in that particular state. 
Table 2

Wage Regressions for Teachers and Aides

\begin{tabular}{|c|c|c|c|c|}
\hline \multirow{2}{*}{$\begin{array}{c}\text { Variable } \\
I\end{array}$} & \multicolumn{2}{|c|}{ Teachers } & \multicolumn{2}{|c|}{ Aides } \\
\hline & II & III & IV & $\mathbf{V}$ \\
\hline INTERCEPT & 0.652 & $(0.162)$ & 1.175 & $(0.182)$ \\
\hline \multicolumn{5}{|c|}{ A. Sector Characteristics } \\
\hline FOR-PROFIT & -0.039 & $(0.048)$ & -0.038 & $(0.053)$ \\
\hline PUBLIC-AUSPICE & $0.256 * *$ & $(0.100)$ & $0.409 * *$ & $(0.093)$ \\
\hline PUBLIC-SUPPORT & 0.056 & $(0.053)$ & 0.034 & $(0.052)$ \\
\hline SPECIAL REGUL & -0.055 & $(0.068)$ & -0.087 & $(0.061)$ \\
\hline RELIGIOUS & $-0.108^{*}$ & $(0.058)$ & $-0.142 * *$ & $(0.052)$ \\
\hline ONSITE & -0.034 & $(0.139)$ & 0.076 & $(0.185)$ \\
\hline NATIONAL CHAIN & -0.036 & $(0.062)$ & -0.034 & $(0.127)$ \\
\hline \multicolumn{5}{|c|}{ B. Human Capital Characteristics } \\
\hline $\mathrm{AGE}$ & -0.0004 & $(0.002)$ & 0.001 & $(0.002)$ \\
\hline TENURE & $0.023 * *$ & $(0.004)$ & $0.023 * *$ & $(0.005)$ \\
\hline EXPERIENCE & $0.014 * *$ & $(0.003)$ & 0.005 & $(0.005)$ \\
\hline EDUCATION & $0.054 * *$ & $(0.010)$ & $0.026^{* *}$ & $(0.011)$ \\
\hline NOTRAINING & $-0.155 * *$ & $(0.061)$ & $-0.085^{*}$ & $(0.050)$ \\
\hline TRAINING-2 & -0.032 & $(0.020)$ & -0.027 & $(0.028)$ \\
\hline TRAINING-3 & $0.042^{*}$ & $(0.024)$ & 0.05 & $(0.032)$ \\
\hline TRAINING-4 & 0.041 & $(0.033)$ & 0.057 & $(0.043)$ \\
\hline TRAINING-5 & 0.004 & $(0.047)$ & -0.023 & $(0.073)$ \\
\hline TRAINING-6 & 0.011 & $(0.024)$ & 0.033 & $(0.033)$ \\
\hline TRAINING-7 & $0.066^{*}$ & $(0.037)$ & 0.013 & $(0.070)$ \\
\hline TRAINING-8 & 0.321 & $(0.238)$ & -0.672 & $(0.584)$ \\
\hline TRAINING-9 & 0.042 & $(0.039)$ & -0.019 & $(0.055)$ \\
\hline TRAINING-10 & $0.118^{*}$ & $(0.062)$ & $0.601 * *$ & $(0.217)$ \\
\hline TRAINING-11 & 0.045 & $(0.080)$ & $-0.234 * *$ & $(0.092)$ \\
\hline \multicolumn{5}{|c|}{ C. Insider-Outsider Characteristics } \\
\hline UNION & $0.173^{* *}$ & $(0.051)$ & $0.157 * *$ & $(0.065)$ \\
\hline SERVICE WAGE & $0.012 * *$ & $(0.005)$ & $0.014 * *$ & $(0.007)$ \\
\hline UNEMP RATE & $0.008^{*}$ & $(0.005)$ & $-0.013 * *$ & $(0.005)$ \\
\hline PROFIT-EC & 0.0003 & $(0.004)$ & $0.014 * *$ & $(0.005)$ \\
\hline \multicolumn{5}{|c|}{ D. Center Characteristics } \\
\hline FTE-CHILDREN & $0.0004 * *$ & $(0.000)$ & -0.0002 & $(0.0002)$ \\
\hline WRJOB & 0.013 & $(0.028)$ & 0.001 & $(0.046)$ \\
\hline WRCONTR & 0.004 & $(0.015)$ & -0.015 & $(0.021)$ \\
\hline WRSAL & $0.056 * *$ & $(0.015)$ & $0.052 * *$ & $(0.021)$ \\
\hline PARTDAY & -0.015 & $(0.020)$ & 0.018 & $(0.029)$ \\
\hline PARTDAYEX & 0.005 & $(0.018)$ & 0.018 & $(0.024)$ \\
\hline HEADSTART & -0.031 & $(0.068)$ & -0.041 & $(0.080)$ \\
\hline BEFORE-AFTER & $-0.059 * *$ & $(0.017)$ & -0.035 & $(0.023)$ \\
\hline WEEKEND & 0.013 & $(0.055)$ & -0.021 & $(0.047)$ \\
\hline CENTER AGE & -0.001 & $(0.001)$ & $-0.002 *$ & $(0.001)$ \\
\hline SUBSIDIZED & -0.054 & $(0.045)$ & -0.081 & $(0.051)$ \\
\hline PRODUCTIVITY & $0.021 * *$ & $(0.011)$ & 0.022 & $(0.015)$ \\
\hline
\end{tabular}


(Table 2 concluded)

\begin{tabular}{|c|c|c|c|c|}
\hline \multirow{2}{*}{$\begin{array}{c}\text { Variable } \\
\text { I }\end{array}$} & \multicolumn{2}{|c|}{ Teachers } & \multicolumn{2}{|c|}{ Aides } \\
\hline & II & III & IV & v \\
\hline CAL & $0.204^{* * *}$ & $(0.044)$ & 0.048 & $(0.059)$ \\
\hline COL & 0.024 & $(0.028)$ & -0.023 & $(0.038)$ \\
\hline $\mathrm{CON}$ & $0.207^{* *}$ & $(0.037)$ & $0.131^{* *}$ & $(0.050)$ \\
\hline \multicolumn{5}{|l|}{ E. Race } \\
\hline WHITE TCH/AIDE & 0.106 & $(0.082)$ & -0.075 & $(0.093)$ \\
\hline WHITE CHILDRN & 0.04 & $(0.065)$ & -0.005 & $(0.063)$ \\
\hline WHTSTAFF*WH & -0.001 & $(0.001)$ & 0.0004 & $(0.001)$ \\
\hline \multicolumn{5}{|l|}{ CHILDREN } \\
\hline PROFIT*WH TCH/AIDE & 0.017 & $(0.064)$ & 0.03 & $(0.063)$ \\
\hline AUSP*WH TCH/AIDE & $-0.232^{*}$ & $(0.127)$ & $-0.477 * *$ & $(0.120)$ \\
\hline REGUL*WH TCH/AIDE & 0.049 & $(0.093)$ & $0.160^{*}$ & $(0.089)$ \\
\hline RELIGIOUS*WH & 0.046 & $(0.074)$ & $0.159 * *$ & $(0.065)$ \\
\hline \multicolumn{5}{|l|}{ TCH/AIDE } \\
\hline ONSITE*WH TCH/AIDE & 0.207 & $(0.178)$ & 0.068 & $(0.249)$ \\
\hline CHAIN*WH TCH/AIDE & -0.023 & $(0.076)$ & -0.016 & $(0.147)$ \\
\hline SUPP*WH TCH/AIDE & $-0.136^{*}$ & $(0.082)$ & -0.030 & $(0.076)$ \\
\hline $\mathrm{R}^{2}$ & \multicolumn{2}{|c|}{0.84} & \multicolumn{2}{|c|}{0.80} \\
\hline $\mathbf{N}$ & \multicolumn{2}{|c|}{344} & \multicolumn{2}{|c|}{205} \\
\hline
\end{tabular}


Table 3

The Impacts of Selected Variables on Wages

\begin{tabular}{|c|c|c|c|c|c|c|}
\hline \multirow[b]{3}{*}{$\begin{array}{l}\text { The impact on wages of } \\
a . .\end{array}$} & \multirow{2}{*}{\multicolumn{3}{|c|}{$\begin{array}{c}\text { Teachers' Wages } \\
\begin{array}{l}\text { Percent White Teachers } \\
\text { in Center }\end{array}\end{array}$}} & \multicolumn{3}{|c|}{ Aides' wages } \\
\hline & & & & \multicolumn{3}{|c|}{$\begin{array}{l}\text { Percent White Aides in } \\
\text { Center }\end{array}$} \\
\hline & $100 \%$ & $50 \%$ & $0 \%$ & $100 \%$ & $50 \%$ & $0 \%$ \\
\hline \multirow{5}{*}{$\begin{array}{l}\text { publicly owned center } \\
\text { publicly supp. center } \\
\text { special regulation center } \\
\text { religious center } \\
\text { unionized center }\end{array}$} & $2 \%$ & $15 \%$ & $28 \%$ & $-7 \%$ & $19 \%$ & $50 \%$ \\
\hline & $-13 \%$ & $-7 \%$ & $0 \%$ & & & \\
\hline & & & & $17 \%$ & $8 \%$ & $0 \%$ \\
\hline & $-10 \%$ & $-10 \%$ & $-10 \%$ & $2 \%$ & $-6 \%$ & $-13 \%$ \\
\hline & $19 \%$ & $19 \%$ & $19 \%$ & $17 \%$ & $17 \%$ & $17 \%$ \\
\hline \multicolumn{7}{|l|}{$\begin{array}{l}\text { The impact on wages of } \\
\text { a } 10 \text { percent increase in }\end{array}$} \\
\hline local averg. serv. wage & $1.6 \%$ & $1.6 \%$ & $1.6 \%$ & $1.9 \%$ & $1.9 \%$ & $1.9 \%$ \\
\hline local unemployment rate & $0.5 \%$ & $0.5 \%$ & $0.5 \%$ & $-0.8 \%$ & $-0.8 \%$ & $-0.8 \%$ \\
\hline center economic profits & & & & $0.1 \%$ & $0.1 \%$ & $0.1 \%$ \\
\hline full-time-equiv. children & $0.3 \%$ & $0.3 \%$ & $0.3 \%$ & & & \\
\hline unobserved productivity & $0.2 \%$ & $0.2 \%$ & $0.2 \%$ & & & \\
\hline \multicolumn{7}{|l|}{$\begin{array}{l}\text { The impact on wages of } \\
\text { an additional year of.. }\end{array}$} \\
\hline tenure at the center & $2.3 \%$ & $2.3 \%$ & $2.3 \%$ & $2.3 \%$ & $2.3 \%$ & $2.3 \%$ \\
\hline prior experience & $1.4 \%$ & $1.4 \%$ & $1.4 \%$ & & & \\
\hline general education & $5.4 \%$ & $5.4 \%$ & $5.4 \%$ & $2.6 \%$ & $2.6 \%$ & $2.6 \%$ \\
\hline \multicolumn{7}{|l|}{$\begin{array}{l}\text { The impact on wages of } \\
\text { a } 10 \text { percentage point } \\
\text { increase in }\end{array}$} \\
\hline $\begin{array}{l}\text { the percent teachers (or } \\
\text { aides) with no } \\
\text { specialized training }\end{array}$ & $-1.5 \%$ & $-1.5 \%$ & $-1.5 \%$ & $-0.8 \%$ & $-0.8 \%$ & $-0.8 \%$ \\
\hline $\begin{array}{l}\text { the percent teachers (or } \\
\text { aides) with training in } \\
\text { workshops }\end{array}$ & $0.4 \%$ & $0.4 \%$ & $0.4 \%$ & & & \\
\hline $\begin{array}{l}\text { the percent teachers (or } \\
\text { aides) with AA degree } \\
\text { in ECE }\end{array}$ & $0.7 \%$ & $0.7 \%$ & $0.7 \%$ & & & \\
\hline $\begin{array}{l}\text { the percent teachers (or } \\
\text { aides) with graduate } \\
\text { courses in ECE }\end{array}$ & $1.2 \%$ & $1.2 \%$ & $1.2 \%$ & $6 \%$ & $6 \%$ & $6 \%$ \\
\hline
\end{tabular}


Table 4

Compensation Regressions for Teachers and Aides

\begin{tabular}{|c|c|c|c|c|}
\hline \multirow{2}{*}{$\begin{array}{c}\text { Variable } \\
\text { I }\end{array}$} & \multicolumn{2}{|c|}{ Teachers } & \multicolumn{2}{|c|}{ Aides } \\
\hline & II & III & IV & $\mathbf{V}$ \\
\hline INTERCEPT & 1.127 & 0.196 & 1.335 & 0.255 \\
\hline \multicolumn{5}{|c|}{ A. Sector Characteristics } \\
\hline FOR-PROFIT & 0.086 & $(0.057)$ & -0.094 & $(0.075)$ \\
\hline PUBLIC-AUSPICE & $0.233^{*}$ & $(0.120)$ & $0.287 * *$ & $(0.130)$ \\
\hline PUBLIC-SUPPORT & 0.056 & $(0.064)$ & 0.050 & $(0.072)$ \\
\hline SPECIAL REGUL & -0.062 & $(0.082)$ & 0.050 & $(0.086)$ \\
\hline RELIGIOUS & $-0.149 * *$ & $(0.069)$ & $-0.160 * *$ & $(0.073)$ \\
\hline ONSITE & 0.019 & $(0.167)$ & 0.232 & $(0.258)$ \\
\hline NATIONAL CHAIN & -0.066 & $(0.074)$ & 0.075 & $(0.178)$ \\
\hline \multicolumn{5}{|c|}{ B. Human Capital Characteristics } \\
\hline AGE & -0.002 & $(0.002)$ & 0.001 & $(0.002)$ \\
\hline TENURE & $0.027^{* *}$ & $(0.005)$ & $0.031 * *$ & $(0.007)$ \\
\hline EXPERIENCE & $0.017 * *$ & $(0.004)$ & $0.013^{*}$ & $(0.007)$ \\
\hline EDUCATION & $0.040^{* *}$ & $(0.012)$ & 0.022 & $(0.015)$ \\
\hline NOTRAINING & $-0.232 * *$ & $(0.074)$ & -0.093 & $(0.070)$ \\
\hline TRAINING-2 & $-0.064 * *$ & $(0.024)$ & $-0.082 * *$ & $(0.039)$ \\
\hline TRAINING-3 & $0.049 *$ & $(0,028)$ & $0.096^{* *}$ & $(0.044)$ \\
\hline TRAINING-4 & 0.031 & $(0.040)$ & 0.031 & $(0.060)$ \\
\hline TRAINING-5 & 0.067 & $(0.057)$ & -0.008 & $(0.103)$ \\
\hline TRAINING-6 & 0.038 & $(0.029)$ & -0.030 & $(0.046)$ \\
\hline TRAINING-7 & 0.060 & $(0.045)$ & 0.082 & $(0.097)$ \\
\hline TRAINING-8 & 0.407 & $(0.286)$ & $-1.632 * *$ & $(0.817)$ \\
\hline TRAINING-9 & 0.063 & $(0.047)$ & -0.041 & $(0.077)$ \\
\hline TRAINING-10 & $0.138^{*}$ & $(0.074)$ & $0.991^{* *}$ & $(0.304)$ \\
\hline TRAINING-11 & 0.124 & $(0.097)$ & -0.165 & $(0.129)$ \\
\hline \multicolumn{5}{|c|}{ C. Insider-Outsider Characteristics } \\
\hline UNION & $0.234 * *$ & $(0.061)$ & $0.290^{* * *}$ & $(0.091)$ \\
\hline SERVICE WAGE & 0.004 & $(0.006)$ & 0.011 & $(0.009)$ \\
\hline UNEMP RATE & 0.006 & $(0.005)$ & -0.008 & $(0.008)$ \\
\hline PROFIT-EC & -0.003 & $(0.004)$ & $0.015^{* *}$ & $(0.007)$ \\
\hline \multicolumn{5}{|c|}{ D. Center Characteristics } \\
\hline FTE-CHILDREN & $0.001 * *$ & 0.000 & 0.0004 & $(0.0003)$ \\
\hline WRJOB & 0.028 & $(0.035)$ & 0.070 & $(0.068)$ \\
\hline WRCONTR & -0.010 & $(0.018)$ & -0.033 & $(0.029)$ \\
\hline WRSAL & $0.064^{* *}$ & $(0.018)$ & 0.046 & $(0.029)$ \\
\hline PARTDAY & -0.022 & $(0.025)$ & 0.023 & $(0.040)$ \\
\hline PARTDAYEX & -0.002 & $(0.022)$ & 0.026 & $(0.034)$ \\
\hline HEADSTART & -0.020 & $(0.082)$ & -0.135 & $(0.112)$ \\
\hline BEFORE-AFTER & $-0.057 * *$ & $(0.020)$ & $-0.104^{* *}$ & $(0.032)$ \\
\hline WEEKEND & -0.034 & $(0.066)$ & -0.082 & $(0.066)$ \\
\hline CENTER AGE & -0.001 & $(0.001)$ & $-0.002 *$ & $(0.001)$ \\
\hline SUBSIDIZED & -0.070 & $(0.054)$ & -0.099 & $(0.071)$ \\
\hline PRODUCTIVITY & $0.027 * *$ & $(0.013)$ & $0.052 * *$ & $(0.021)$ \\
\hline
\end{tabular}


(Table 4 concluded)

\begin{tabular}{|c|c|c|c|c|}
\hline \multirow{2}{*}{$\begin{array}{c}\text { Variable } \\
\text { I }\end{array}$} & \multicolumn{2}{|c|}{ Teachers } & \multicolumn{2}{|c|}{ Aides } \\
\hline & II & III & IV & $\mathbf{V}$ \\
\hline CAL & $0.258 * *$ & $(0.053)$ & 0.088 & $(0.082)$ \\
\hline $\mathrm{COL}$ & 0.048 & $(0.034)$ & 0.019 & $(0.053)$ \\
\hline CON & $0.316^{* *}$ & $(0.044)$ & $0.222 * *$ & $(0.070)$ \\
\hline \multicolumn{5}{|l|}{ E. Race } \\
\hline WHITE TCH/AIDE & 0.073 & $(0.098)$ & -0.114 & $(0.130)$ \\
\hline WHITE CHILDREN & 0.112 & $(0.078)$ & 0.018 & $(0.089)$ \\
\hline WHTSTAFF*WH & $-0.002 *$ & $(0.001)$ & 0.0001 & $(0.002)$ \\
\hline \multicolumn{5}{|l|}{ CHILDREN } \\
\hline PROFIT*WH TCH/AIDE & 0.059 & $(0.077)$ & 0.068 & $(0.088)$ \\
\hline AUSP*WH TCH/AIDE & -0.123 & $(0.152)$ & -0.256 & $(0.168)$ \\
\hline REGUL*WH TCH/AIDE & 0.041 & $(0.111)$ & 0.022 & $(0.125)$ \\
\hline RELIGIOUS*WH & 0.111 & $(0.089)$ & 0.144 & $(0.091)$ \\
\hline \multicolumn{5}{|l|}{ TCH/AIDE } \\
\hline ONSITE*WH TCH/AIDE & 0.194 & $(0.213)$ & -0.218 & $(0.348)$ \\
\hline CHAIN*WH TCH/AIDE & 0.032 & $(0.091)$ & -0.132 & $(0.205)$ \\
\hline SUPP*WH TCH/AIDE & -0.080 & $(0.098)$ & 0.024 & $(0.106)$ \\
\hline$\overline{R^{2}}$ & \multicolumn{2}{|c|}{0.82} & \multicolumn{2}{|c|}{0.70} \\
\hline $\mathbf{N}$ & \multicolumn{2}{|c|}{343} & \multicolumn{2}{|c|}{204} \\
\hline
\end{tabular}

* indicates significance at the 5 percent level; ${ }^{*}$ indicates significance at the 10 percent level 


\section{APPENDIX}

\section{A Bargaining Model}

Consider a bargaining model as described by Blanchflower, Oswald and Sanfey (1996), and Oswald (1982), where supernormal profits are shared between workers and the employer. The maximization problem can be written as

(1A) Maximize $\eta \ln \left\{\left[u(w)-u\left(w^{*}\right)\right] n\right\}+(1-\eta) \ln \pi$,

where $\eta$ is the bargaining power of the workers, $u(w)$ is the worker's utility from wage $w, w^{*}$ is the wage available elsewhere, $n$ is employment and $\pi$ stands for profits, which is equal to $f(n)-w n$, where $f$ is a concave revenue function. An interior optimum, satisfying the condition that both the workers and the firm should earn at least what is available as an outside option, yields

(2A) w: $\left\{\eta u^{\prime}(w) /[u(w)-u(w)] n\right\}-\{1-\eta / \pi\}=0$ and

(2B) $\mathrm{n}:\{\eta / \mathrm{n}\}+\left\{(1-\eta)\left(\mathrm{f}^{\prime}(\mathrm{n})-\mathrm{w}\right) / \pi\right\}=0$.

Using the first-order Taylor series approximation to $u\left(w^{*}\right)$, Equation (3A) can be

re-written as $\quad(3 A) \quad w \approx w^{*}+(\eta / 1-\eta)(\pi / n)$.

Equation (3A) shows that the equilibrium wage is a function of the outside wage available to the workers, the relative bargaining strength of the workers and the profits per worker. Following Blanchlower and Oswald (1994) and the literature they cite, w* can be described by the going wage in the other similar sectors of the economy and the unemployment rate in the locality of the firm. Thus, the empirical counterpart of the wage equation of the bargaining model as an extension of the standard earnings equation is

(4A) $\ln w=g(H, X, \pi / n, u, \omega)$,

where $\mathrm{H}$ and $\mathrm{X}$ are vectors of explanatory variables capturing human capital and firm attributes, $\pi / n$ is the profit per worker of the firm, $u$ is the local unemployment rate, and $\omega$ stands for the alternative wage of the workers. The model predicts that all else being the 
same, higher profits-per-worker should be associated with higher wages, unemployment should be negatively related to wages, and alternative wages should be positively related to wages.

Note that the framework described above assumes the existence supernormal profits to be distributed between the workers and the firm. Blanchflower and Oswald (1994) show that in a perfectly competitive product market where the profits are zero in the long-run, the positive relationship between profitability-per-employee and the wages still holds as long as the demand for labor is less than unity, which is the case for day care centers (Mocan 1997).

An alternative model of wage determination is the labor contract model of Baily (1974) and Azariadis (1975), where firms maximize their expected profits which depend on the changes in product price. Profits are maximized subject to the expected utility of the workers, which is a convex combination of utility from having a job and the utility from being unemployed. This model also predicts a negative association between wages and unemployment. Furthermore, the elasticity of wages with respect to profits is positive if both workers and the firm are risk averse. Contract theory, however, assumes that the firms and the workers perceive themselves to be in a lasting relationship. Thus, the empirical relevance of this model should be higher for the type of workers with low turnover.

\section{Calculation of Compensation}

Hourly compensation is the sum of hourly wages used plus hourly non-wage benefits.

To calculate hourly nonwage benefits for teachers and aides we implemented the following algorithm. (1) The data set includes information on whether nonwage benefits employed are provided for teachers, aides and part-timers. Out of these nonwage benefits we considered the ones that are associated with monetary expenses for the center (e.g. the provision of retirement benefits, paid health insurance, etc.). For each type of worker (teacher, aide, part-timer), we counted the number of benefits offered by the center, and calculated the number of benefits offered to each group as a proportion of the total number of benefits offered to all three groups. (2) We calculated the total full-time teacher hours, total full-time aide hours, and the total part-time hours (teachers and aides). (3) Using 1 and 2, we calculated the share of benefits offered to teachers and aides, weighted by total full-time teacher hours, and aide hours, respectively. (4) The weighted benefit shares obtained in 3 for group $i$ (teachers, aides or part-timers) divided by the sum of the weighted shares for all three groups and multiplied by the total monetary value of nonwage benefits gave us the monetary value of nonwage benefits provided for full-time workers in group $i$. (5) Dividing the value obtained in 4 by total annual hours worked by workers in the $i$ th category gave us the hourly value of nonwage benefits for workers in the ith category. (6) Adding 5 to hourly wages generated hourly compensation. 


\section{REFERENCES}

Abowd, J., and T. Lemieux, 1993, "The Effects of Product Market Competition on Collective Bargaining Agreements: The Case of Foreign Competition in Canada," Quarterly Journal of Economics, 108: 983-1014.

Antos, Joseph R. and Sherwin Rosen, 1975, "Discrimination in the Market for Public School Teachers," Journal of Econometrics; 3:2; pp. 123-50.

Azariadis, Costas, 1975. "Implicit Contracts and Underemployment Equilibria,: Journal of Political Economy 83: 1183-1202.

Bailey, Martin N, 1974 "Wages and Employment Under Uncertain Demand." Review of Economic Studies 41: 37-50.

Beaudry, Paul and John DiNardo, 1991, "The Effect of Implicit Contracts on the Movement of wages over the Business Cycle: Evidence from Micro Data," Journal of Political Economy, pp. $65-88$

Bhargava, Sandeep, 1994, "Profit-Sharing and the Financial Performance of Companies:

Evidence from U.K. Panel Data," Economic Journal; 104, pp. 1044-56.

Blanchflower, David G., Andrew J. Oswald and Peter Sanfey, 1996, "Wages, Profits and Rent-Sharing," Quarterly Journal of Economics, 227-51.

Blanchflower, David G. and Andrew J. Oswald, 1994, The Wage Curve, MIT Press.

Blanchflower, David G., Andrew J. Oswald and Mario D. Garrett, 1990, "Insider Power in Wage Determination," Economica, 57: 143-70.

Blank, Rebecca M., 1990, "Are Part-Time Jobs Bad Jobs?" In A future of Lousy jobs? The changing structure of U.S. wages. Washington D.C.: Brookings Institution, pp. 123-55.

Blau, David M. 1997a, "The Effect of Child Care Characteristics on Child Development," mimeo, University of North Carolina at Chapel Hill.

Blau, David M. 1997b, "The Production of Quality in Child Care Centers, " Journal of Human Resources, 32:2, pp. 354-87.

Blau, David M., 1993, "The Supply of Child Care Labor," Journal of Labor Economics, $11: 2$, pp. $324-47$.

Blau, David M., 1992, "The Child Care Labor Market," The Journal of Human Resources, 27:1, pp. 9-39.

Borjas, George J., H. E. Frech III, and Paul B. Ginsberg, 1983, "Property Rights and Wages: The Case of Nursing Homes." Journal of Human Resources, 18:2, pp. 231-46. 
Brown, C. and James Medoff, 1989, "The Employer size wage Effect," Journal of Political Economy, 101: 483-96.

Brown, Charles, 1980, "Equalizing Differences In The Labor Market," Quarterly Journal of Economics, 94: 113-34.

Cappelli, Peter and Keith Chauvin, 1991, "An Interplant Test of the Efficiency Wage Hypothesis," Quarterly Journal of Economics; 106:3 pp. 769-87.

Card, David, 1995, "The Wage Curve: A Review," Journal of Economic Literature, pp. 78599.

Carruth A. and Andrew Oswald, 1987, "On Union Preferences and Labour market Models: Insiders and Outsiders," Economic Journal, 97: 431-45.

Christofides, L.N., and Andrew J. Oswald, 1992, "Real Wage Determination and RentSharing in Collective Bargaining Agreements," Quarterly Journal of Economics, 985-1002.

Currie, Janet and Sheena McConnell, 1992, "Firm-Specific Determinants of the Real Wage" The Review of Economics and Statistics, 297-304.

Dickens W.T., and Lawrence Katz, 1987, "Inter-Industry Wage Differences and Industry Characteristics, " in Unemployment and the Structure of Labour Markets, K. Lang and J. Leonard (eds.), Oxford: Basic Blackwell.

Doms, Mark, Timothy Dunne, and Kenneth Troske, Kenneth, 1997, "Workers, Wages, and Technology," Quarterly Journal of Economics; 112:1, pp. 253-90.

Estevao, Marcello and Stacey Tevlin, 1995, "The Role of Profits in Wage Determination: Evidence from U.S. Manufacturing, "Board of Governors of the Federal Reserve Discussion Paper, 95/48.

Evans D. S., and L. S. Leighton, 1989, "Why Do Smaller Firms Pay Less?" Journal of Human Resources, 24: 299-318.

Goodman, William, 1995, "Boom in Day Care Industry the Result of Many Social Changes," Monthly Labor Review, August: 3-12.

Groshen, Erica L., 1991a, "Sources of Intra-Industry Wage Dispersion: How Much Do Employers Matter?" Quarterly Journal of Economics, pp. 869-84.

Groshen, Erica L., 1991b, "Five Reasons Why Wages Vary among Employers." Industrial Relations, 30:3, pp. 350-81

Hall, Robert, 1970, "Why is the Unemployment Rate So High at Full-Employment?" Brookings Papers on Economic Activity, 3:369-485.

Hansmann, Henry B.,1986, "The Role of Nonprofit Enterprise," In The Economics of Nonprofit Institutions, Susan Rose-Ackerman, ed. Oxford University Press. 
Harris J. and M. P. Todero, 1970, "Migration, Unemployment and Development: A TwoSector Analysis," American Economic Review 60: 126-142

Hildreth, Andrew K.G. and Andrew J. Oswald, 1997, "Rent-Sharing and Wages: Evidence from Company and Establishment Panels," Journal of Labor Economics, 15:2. pp. 318-37.

Jovanovic, Boyan, 1979a, "Firm-specific Capital and Turnover," Journal of Political Economy, 87:6, pp. 1246-60.

Jovanovic, Boyan, 1979b, "Job Matching and the Theory of Turnover. " Journal of Political Economy, 87:5, part I. pp. 972-90.

Katz, Lawrence, 1988, "Recent Developments in Labor Economics and Their Implications for Macroeconomics," Journal of Money Credit and Banking.

Kennedy, Peter. 1981. "Estimation with Correctly Interpreted Dummy Variables in Semilogarithmic Equations." American Economic Review 71:801.

Kenny, Lawrence and David Denslow Jr., 1980. "Compensating Differentials and Teachers' Salaries." Journal of Urban Economics, 7: 198-207.

Krueger, Alan, 1997, "Experimental and Non-Experimental Estimates of Education Production Functions," mimeo, Princeton University.

Krueger, Alan B., and Lawrence H. Summers, 1988, "Efficiency Wages and the Inter-Industry Wage Structure," Econometrica, 56: 259-93.

Krueger, Alan B. and Lawrence H. Summers, 1987 "Reflections on the Inter-industry Wage Structure, " in Unemployment and the Structure of Labour Markets, K. Lang and J. Leonard (eds.), Oxford: Basic Blackwell.

Lazar, Irving and Richard Darlington, 1982, "Lasting Effects of Early Education: A Report from the Consortium for Longitudinal Studies, " Chicago: University of Chicago press.

Lindeck, Assar and Dennis J. Snower, 1988, The Insider-Outsider Theory of Employment and Unemployment, Cambridge, Massachusetts: MIT Press.

Main, Brian G. M. and Barry Reilly, 1993, "The Employer Size-Wage Gap: Evidence For Britain," Economica, Vol. 60, pp. 125-42.

Mayhew, K. and B. Rosewell, 1979, "Labour Market Segmentation in Britain," Oxford Bulletin of Economics and Statistics; 41:2; pp. 81-115.

Mocan, H. Naci, 1997, "Cost Functions, Quality and Efficiency in Day Care Centers," Joumal of Human Resources, Fall, Vol. 32:4.

Mocan, H. Naci, 1995, "Quality-Adjusted Cost Functions For Child Care Centers, " American Economic Review Papers and Proceedings, 85:2, pp.409-13 
Mocan, H. Naci, Margaret Burchinal, John Morris and Suzanne Helburn, 1995, "Models of Quality in Center Child Care, in Cost, Quality and Child Outcomes in Child Care Centers, Suzanne Helburn ed; Denver: Center for Research on Economic and Social Policy.

Neuman, Shoshana and Adrian Ziderman, 1986, "Testing the Dual Labor Market Hypothesis: Evidence from the Israel Labor Mobility Survey, "Journal of Human Resources; $21: 2$; pp. 230-37.

Nickell, S., J. Vainiomaki, and S. Wadhwani, 1994, "Wages and Product Market Power," Economica, pp. 457-73.

Nolan, Peter and William Brown, 1983; "Competition and Workplace wage Determination," Oxford Bulletin of Economics and Statistics, pp. 269-87.

Oswald, Andrew J., 1982a, "Trade Unions, Wages and Unemployment: What Can Simple Models Tell Us?" Oxford Economic Papers, 34:3, pp. 526-45.

Oswald, Andrew J., 1982b, "The Microeconomic Theory of the Trade Union." Economic Journal, 92:367, pp. 576-95.

Preston, Anne E., 1989, "The Nonprofit Worker in a For-Profit World," Journal of Labor Economics, Vol 7:4, pp. 438-63.

Preston, Anne E., 1988, "The Effects of Property Rights on Labor Costs on Nonprofit Firms: An Application to the Day Care Industry, "The Journal of Industrial Economics, XXXVI: 337 50.

Ramey, Craig and Frances Campbell, 1991, "Poverty, Early Cildhood Education and Academic Competence: The Abecedarian Experiment," in Children in Poverty: Child Development and Public Policy, A. Houston (ed.) New York: Cambrideg University Press.

Rosen, Sherwin, 1986, "The Theory of Equalizing Differences," in Handbook of Labor Economics, Orley Ashenfelter and Richard Layard(eds.);ed. Vol. 1.

Amsterdam: North-Holland

Ruopp, Richard, Jeffrey Travers, Frederic Glants and Craig Coelen. 1979, Children at the Center. Cambridge: Abt Books.

Toder, Eric J, 1972, "The Supply of Public School Teachers to an Urban Metropolitan Area: A Possible Source of Discrimination in Education, "Review of Economics and Statistics; 54:4, pp. 439-43.

Vardell, Rosemarie and Marcy Whitebook, 1995, "Worthy Work, Worthless Wages, "Dollars and Sense, Sep-Oct

Whitebook, Marcy, Carolle Howes, and Deborah Phillips, 1990, "Who cares? Child Care Teachers and the Quality of Care in America," Final Report of the National Child Care Staffing Study. Oakland, California: Child Care Employee Project. 